
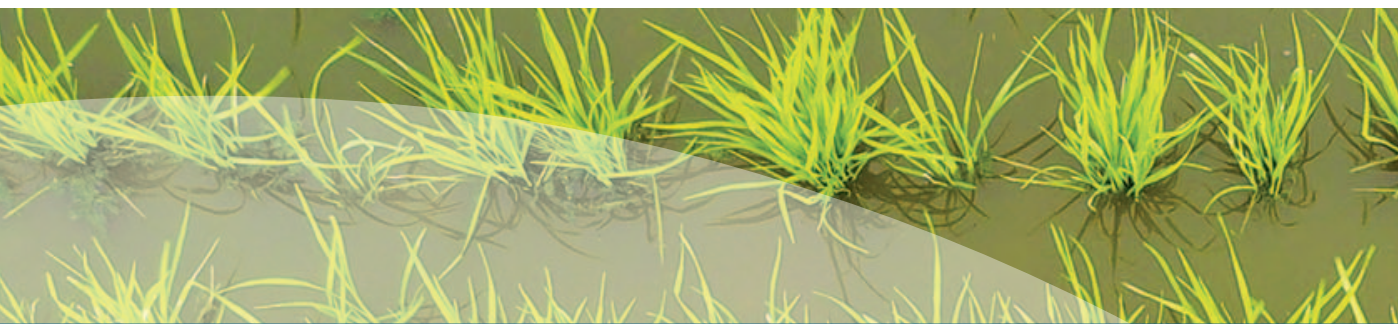

1hil
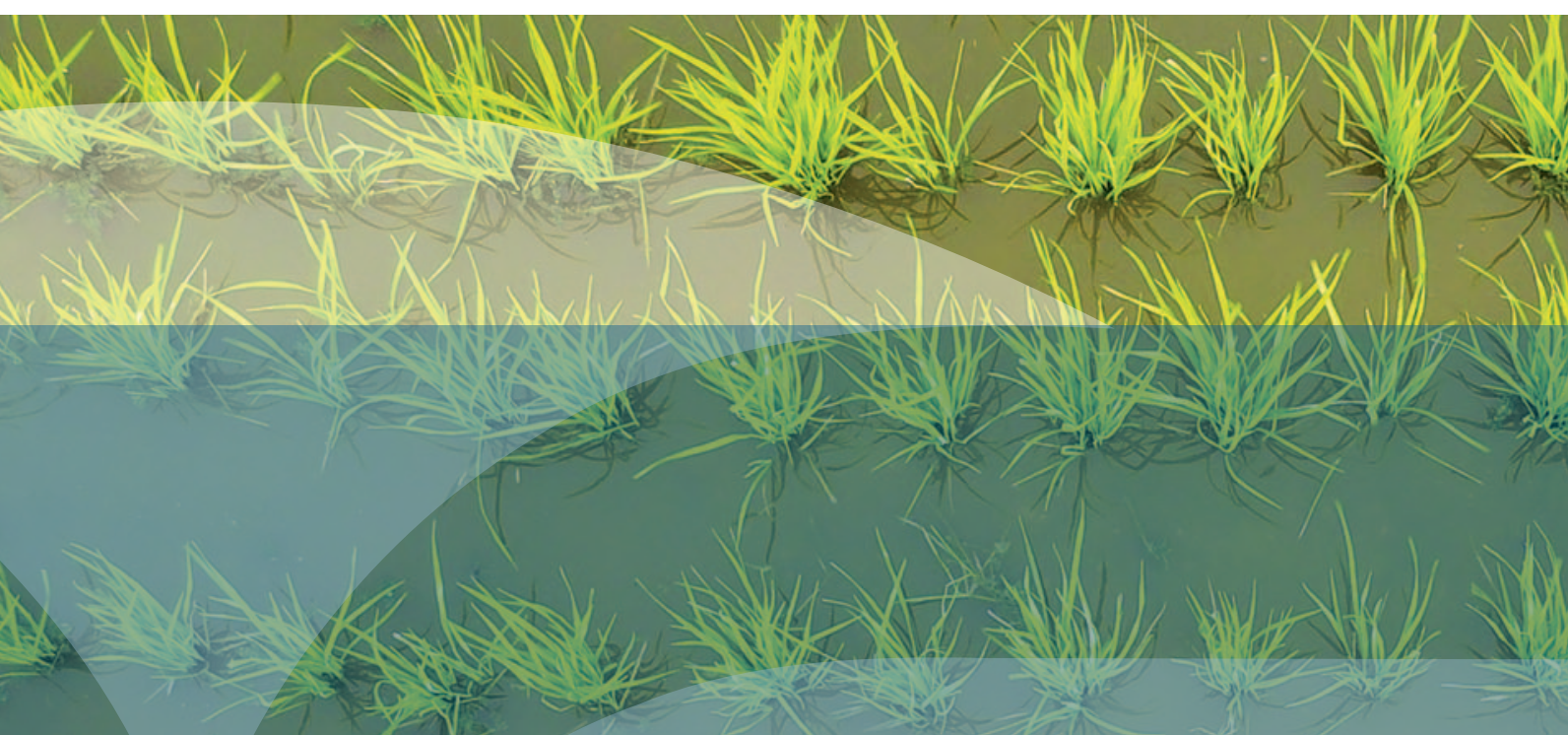

INNOVATIVE

FINANCING SOLUTIONS

\title{
FOR COMMUNITY SUPPORT IN THE CONTEXT OF LAND INVESTMENTS
}

REPORT MARCH 2019

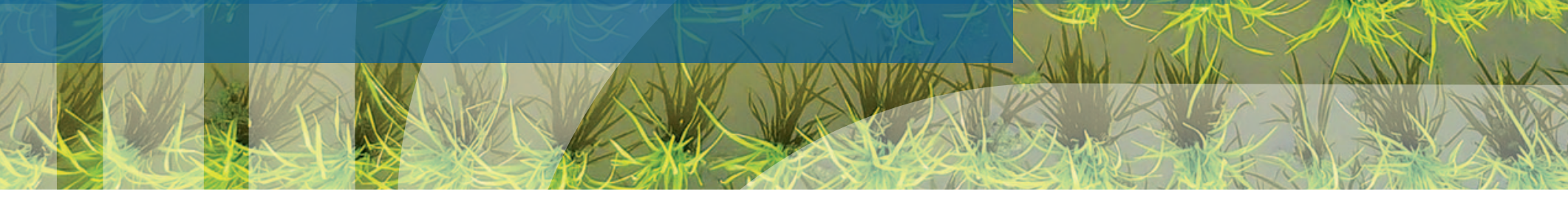




\section{TABLE OF CONTENTS}

WHO IS THIS REPORT FOR?

EXECUTIVE SUMMARY

THE DESPERATE NEED FOR INCREASED FINANCING FOR COMMUNITY SUPPORT

The current state of financing

What types of support do communities need more of?

FINANCING SOLUTIONS

1. Government marshaling

2. Basket funds

3. Impact investing

4. Third party funding

5. Direct company funding

6. Other solutions for financing support or reducing costs

\section{OVERARCHING CONSIDERATIONS}

The amount of money needed

Efficiency, effectiveness, and sustainability 


\section{WHO IS THIS REPORT FOR?}

- Donors, including philanthropic foundations and bilateral and multilateral aid donors, concerned with land governance and land rights, access to justice and Sustainable Development Goal (“SDG”) 16 (Peace, justice and strong institutions), community legal empowerment, benefit sharing, corporate accountability, and/or environmental justice, among other fields.

- Communities who have been or stand to be affected by investment projects, and who hope to find new ways to finance the legal support they need, as well as the civil society organizations ("CSOs") that work with those communities or on policy issues around responsible land investments.

- Governments hosting land investments (referred to as "host governments").

- Companies that conduct land investment, such as agricultural or forestry projects (referred to as "investor companies" or "companies"), seeking stable and cooperative working relationships with host communities.

- Development Finance Institutions (“DFIs"), such as the International Finance Corporation or government-owned finance institutions, potentially as well as commercial banks and financiers, whose clients undertake land investments.

- Commodity buyers, such as food and beverage companies and other companies in a range of industries, that buy agricultural or forest commodities.

- Multi-stakeholder initiatives ("MSIs") and other bodies with members who include investor companies or commodity buyers.

- Impact investors interested in improving the social and environmental impacts of land investments.

- $\quad$ Lawyers who support communities affected by investment.

\section{Acknowledgments}

This report was funded by UKaid from the Department for International Development, although the views expressed do not necessarily represent those of the UK government.

This report was written primarily by Sam Szoke-Burke, a legal researcher at the Columbia Center on Sustainable Investment (CCSI), with additional writing and editorial support from Kaitlin Y. Cordes, Head of Land and Agriculture at CCSI. Research for the paper was conducted by CCSI staff Sam Szoke-Burke, Pedro Villegas, Kaitlin Y. Cordes, and Tehtena Mebratu-Tsegaye. We are grateful for additional research support from Chantarella De Blois, Nadeeya Saleh, Bert Simeons, Aarthi Sridharan, and Victoria Xie. We would like to thank Joanne Bauer, David Burke, Matthew Burnett, Heather Eisenlord, Brooke Güven, Chris Jochnick, James Otto, Pedro Villegas, and one anonymous reviewer for their helpful reviews, and Nathan Lobel for his editorial assistance.

\section{Methodology}

Research for this report involved desktop research, as well as confidential interviews with 39 representatives from civil society, companies, multi-stakeholder initiatives, academia, and the impact investment, development finance (and a related accountability mechanism), philanthropic, and legal technology sectors, conducted from July 2017 to March 2019. We extend our sincere gratitude to all interviewees.

Cover image Rice paddy. @ shuttersrock/nelzajamal. Design Onehemisphere.se Illustrations on $p .13$ by Nnaemeka Ekeocha: +234 8125768790, +2348034924215, jornigun@gmail.com. Printed 100\% recycled paper using non-toxic inks and renewable wind-powered energy. 
"The Malen situation is a classic example of how not to conduct large-scale land acquisitions .... A company relies on the government to acquire land for its investment, the government gives instructions to the Paramount Chief, who then requires that the sub-chiefs make the land available. A lease agreement is drawn up by a government lawyer and ... thumb-printed by a few community members who do not understand its content... [E]ven though money is paid and a document drawn up by a lawyer is signed, it still feels like a forceful taking, a dispossession clothed in legality. It reads like a collusion between the government and the investor-an alliance of the powerful and wealthy-to strip a community of their most valuable resource. Unsurprisingly, [the investor] has had to rely heavily on the powers of the government to deal with the resentment against the deal."

Sonkita Conteh 




Communities affected by agricultural, forestry, and other resource investments urgently need increased funding for legal and technical support. Too many communities struggle to access the support they need to protect their interests, in large part because they cannot afford it. This is in stark contrast to companies, who can generally afford the legal and technical support needed for their investments. Inadequate support can weaken a community's ability to: prepare internally; influence due diligence and planning; consult and interact with a company about a proposed project; negotiate a contract with a company; monitor company operations; engage in dispute resolution; litigate and enforce relevant judgments; and ensure responsible project closure. As a result, communities around the world risk losing access to critical land and resources, suffering human rights violations, or missing opportunities to benefit from investments. The inability of communities to secure necessary support can also result in conflict and challenges that are damaging for companies, host governments, and other actors. 
Although donors, support providers, and others have found ways to support communities directly and indirectly, their combined efforts can only extend so far. To fill the financing gap, promising new opportunities exist. But they require both catalytic and sustained efforts by a range of different actors, and present their own challenges, which must be carefully addressed. This report presents a call to action for different stakeholders to help communities secure the support they so crucially need.

\section{FINANCING OPTIONS}

In the context of investment, communities often require the services of CSOs, paralegals, organizers, non-legal experts, lawyers, or other actors. Yet for each investment-related process necessitating some form of community support, certain financing options may be better suited than others. Nonetheless, an approach that finances community support both before the project (preparation, consultation, negotiation) and afterwards (monitoring, dispute resolution, closure) reinforces and enhances the impact of any support given.

\section{Government marshaling}

Host governments seeking to foster productive, conflict-free investments and attract responsible companies can finance community support by collecting additional money from companies and other actors, using taxes, fees, and penalties. In designing those mechanisms, governments will need to balance the goal of generating revenue with what is politically feasible. Other options governments can pursue to finance community legal support include collecting additional revenue from the legal profession, and using social impact bonds to marshal funding from impact investors.

\section{Basket funds}

By collecting money from multiple sources, basket funds can move beyond traditional philanthropic and aid donors to secure funding from companies and other actors. Basket funds offer the promise of securing funding from private sector actors while minimizing their actual or perceived influence over communities and support providers. This is done by securing multiple funding sources to "dilute" the influence of any single funding source, and having a third party entity administer and pay out money.
Contributing to a basket fund can help companies understand and incorporate community perspectives into the investment project's design, work towards obtaining the community's "social license to operate," and avoid or resolve costly conflict. Aside from companies, other private sector actors may be motivated to participate in order to increase compliance with relevant performance standards or sustainability commitments. Donors may be interested in contributing to basket funds that complement and extend the reach of existing philanthropic efforts to finance community support, and that present strategies for achieving financial sustainability.

\section{Impact investments}

Impact investments, which seek to achieve both a positive impact and a financial return, could theoretically be used to finance a small subset of community support needs. Specifically, impact investments may feasibly finance support: for negotiating benefit agreements that are expected to generate significant revenue for communities; for litigation where the community is seeking a substantial damages award; or using social impact bonds, where the funding for community support is repaid by a government or other "outcome payer" if the support achieves a pre-defined goal.

\section{Third party funding}

Third party funders occasionally finance community support to litigate damages claims, such as for large-scale environmental pollution. Litigation funders usually finance the litigation costs in exchange for a financial interest in the outcome of the case. While funders may offer financial and strategic might to inexperienced community claimants, they also risk interfering with the lawyer-client relationship and influencing the litigation's conduct in ways that may not be in the community's interests. Third party funding is less feasible and appropriate in contexts where legal frameworks are not adequately developed or where rule of law is weak.

\section{Direct company funding}

While companies may wish to directly finance community support in relation to specific company projects, such an approach should be considered with extreme caution. The community or its support provider may be unduly influenced by the knowledge that the company is financing the support. In addition, direct company funding cannot comprehensively increase community access to support. 


\section{Other solutions}

Supplementary funding can be raised through crowd funding, earmarked profits from social enterprises, and community members themselves, either by paying affordable fees or providing in-kind services. Further, support providers can sometimes use contingency or uplift fees, meaning that they will only be paid if a successful outcome is achieved. In addition, fee shifting laws in some jurisdictions may entitle successful community claimants to have their support costs paid by the losing counter party.

\section{OVERARCHING CONSIDERATIONS}

Stakeholders seeking to develop a financing initiative must address a range of considerations. These include:

- The amount of money needed. An initiative's likely cost will be affected by community preferences and needs regarding support and the initiative's focus and scope. Data can be generated and used to understand likely needs and cost.

- Efficiency, effectiveness, and sustainability. Strategies are needed to reduce costs and to ensure an initiative's financial sustainability. Effectiveness can be improved by: matching financing options to specific support needs; managing political complexity and obstacles; addressing the political economy implications of making more funding available; and employing appropriate governance mechanisms.

- Links between the initiative, communities, and support providers. The logistics required to link money, communities, and support providers may be affected by whether or not local CSOs can act as a bridge between financing initiatives and communities; the options available where no relevant local CSO exists; and determinations about who should receive money from the financing initiative and pay each support provider.

\section{RECOMMENDATIONS}

In addition to current grant making efforts-which are and will remain crucial-donors should: help establish new financing initiatives, especially basket funds, given their potential to become self-sustaining; facilitate cooperation between different stakeholders; and continue to advance strategies for supporting the next generation of global south-based community support providers.

Host governments can establish initiatives to finance community support, including through the marshaling of additional revenue. Governments should sensitize companies about the importance of adequate community support, and establish appropriate legal frameworks to facilitate and regulate different financing initiatives.

Communities and the CSOs that support them can use the solutions and considerations in this report to guide concrete funding requests, demands, advocacy campaigns, and negotiation strategies. Those interested in promoting such opportunities should identify strategic moments to advance arguments and ideas for establishing expansive and robustly governed financing solutions.

Agribusiness, forestry, and other natural resource companies should finance basket funds that apply beyond individual projects, and should commit to contributing resources regularly, on a long-term basis.

Buyers, DFIs, private financiers, MSIs and other bodies with company members should consider contributing funding to basket funds and encourage or require companies within their spheres of influence to do so as well.

Impact investors and impact investment funds should continue to explore investing in community support, and ensure that any investments avoid onerous and unrealistic repayment obligations for communities.

Fee-charging lawyers working for communities should: investigate and pursue best practices with respect to contingency or uplift fees; explore ways to reduce costs, including by unbundling legal tasks; and consider accepting in-kind repayments or charging affordable user fees. For litigated matters, lawyers should ensure that any third party funding agreements protect the lawyer-client relationship and preserve community control over the litigation; lawyers should also consider applying to courts for advance funding of communities' costs before cases proceed or for fee shifting after cases have concluded. 


\section{TABLE 1: OVERVIEW OF FINANCING SOLUTIONS}

\begin{tabular}{|c|c|c|c|}
\hline Financing solution & $\begin{array}{l}\text { Funding } \\
\text { source }\end{array}$ & $\begin{array}{l}\text { Investment-related processes that could be } \\
\text { covered }\end{array}$ & Main benefits and challenges \\
\hline $\begin{array}{l}\text { Government } \\
\text { marshaling of funding } \\
\text { from companies and } \\
\text { other actors, through } \\
\text { taxes, fees, and } \\
\text { penalties levied on } \\
\text { different investment- } \\
\text { related activities, such } \\
\text { as permit applications }\end{array}$ & $\begin{array}{l}\text { Companies, } \\
\text { other taxable } \\
\text { entities }\end{array}$ & $\begin{array}{l}\text { - Preparing internally before engaging with a company } \\
\text { - Influencing due diligence and planning } \\
\text { - Consultation and initial interactions with a company } \\
\text { - Negotiating (or re-negotiating) a contract with a } \\
\text { - } \text { - Monpany } \\
\text { - Disputering and fact-finding } \\
\text { - Litigation } \\
\text { - Project closure and rehabilitation }\end{array}$ & $\begin{array}{l}\text { BENEFITS } \\
\text { - Could help fulfill governments' human rights } \\
\text { obligations and development commitments } \\
\text { - Governments have power to tax and charge penalties } \\
\text { CHALLENGES } \\
\text { - Risk of misappropriation } \\
\text { - Potentially hard to marshal enough money to meet } \\
\text { support needs }\end{array}$ \\
\hline $\begin{array}{l}\text { Basket funds, } \\
\text { operated by } \\
\text { independent, trusted } \\
\text { entities and funded by } \\
\text { contributions from a } \\
\text { range of actors }\end{array}$ & $\begin{array}{l}\text { Companies, } \\
\text { commodity } \\
\text { buyers, DFls, } \\
\text { donors }\end{array}$ & $\begin{array}{l}\text { - Preparing internally before engaging with a company } \\
\text { - Influencing due diligence and planning } \\
\text { - Consultation and initial interactions with a company } \\
\text { - Negotiating (or re-negotiating) a contract with a } \\
\text { - Mompany } \\
\text { - Monitoring and fact-finding } \\
\text { - Project closure and rehabilitation }\end{array}$ & $\begin{array}{l}\text { BENEFITS } \\
\text { - Accesses new and relevant funding sources } \\
\text { - Potential to access large amounts of money } \\
\text { CHALLENGES } \\
\text { - Will not work unless strong and innovative governance } \\
\text { approaches to mitigate risk of undue influence by } \\
\text { company or financial mismanagement by fund manager }\end{array}$ \\
\hline $\begin{array}{l}\text { Market-based impact } \\
\text { investments, including } \\
\text { those made as loans to } \\
\text { communities, repayable } \\
\text { with interest or at a } \\
\text { premium }\end{array}$ & $\begin{array}{l}\text { Impact } \\
\text { investors } \\
\text { (including } \\
\text { donors) }\end{array}$ & $\begin{array}{l}\text { - Negotiating (or re-negotiating) a contract with a } \\
\text { company (provided it is likely to include significant } \\
\text { sharing of revenues with the community) } \\
\text { - Litigation (only damages claims where a large } \\
\text { amount of money is sought) }\end{array}$ & $\begin{array}{l}\text { BENEFITS } \\
\text { - ACcesses new funding sources } \\
\text { CHALLENGES } \\
\text { - High transactional costs and data needs } \\
\text { - Only applicable to communities seeking very large } \\
\text { amounts of money from their counter-party or the } \\
\text { underlying project }\end{array}$ \\
\hline $\begin{array}{l}\text { Social impact bonds, } \\
\text { a form of impact } \\
\text { investment where the } \\
\text { money advanced to } \\
\text { pay for community } \\
\text { support is to be repaid } \\
\text { by a government or } \\
\text { other "outcome payer" } \\
\text { if the support achieves } \\
\text { a pre-defined goal }\end{array}$ & $\begin{array}{l}\text { Governments, } \\
\text { donors, and } \\
\text { others willing } \\
\text { to act as } \\
\text { outcome } \\
\text { payers }\end{array}$ & $\begin{array}{l}\text { - Preparing internally before engaging with a company } \\
\text { - Influencing due diligence and planning } \\
\text { - Consultation and initial interactions with a company } \\
\text { - Negotiating (or re-negotiating) a contract with a } \\
\text { - Mompany } \\
\text { - Monitoring and fact-finding } \\
\text { - Litigation }\end{array}$ & $\begin{array}{l}\text { BENEFITS } \\
\text { - OutCome payers only pay for successful initiatives } \\
\text { CHALLENGES } \\
\text { - Still requires public or donor funds to finance successful } \\
\text { community support }\end{array}$ \\
\hline $\begin{array}{l}\text { Direct company } \\
\text { funding of community } \\
\text { support }\end{array}$ & Companies & $\begin{array}{l}\text { - Project closure and rehabilitation } \\
\text { - Preparing internally before engaging with a company } \\
\text { - Influencing due diligence and planning } \\
\text { - Consultation and initial interactions with a company } \\
\text { - Negotiating (or re-negotiating) a contract with a } \\
\text { - Mompany } \\
\text { - Monitoring and fact-finding } \\
\text { - Project closure and rehabilitation }\end{array}$ & $\begin{array}{l}\text { BENEFITS } \\
\text { - COMPanies have proven willing to provide direct funding } \\
\text { CHALLENGES } \\
\text { - High risk of perceived or actual undue influence }\end{array}$ \\
\hline $\begin{array}{l}\text { Third party funding, } \\
\text { usually of support } \\
\text { costs for litigation, in } \\
\text { exchange for a } \\
\text { financial interest in the } \\
\text { outcome of the } \\
\text { support }\end{array}$ & $\begin{array}{l}\text { Third party } \\
\text { litigation } \\
\text { funders }\end{array}$ & $\begin{array}{l}\text { - Litigation (provided a sufficiently large amount of } \\
\text { damages is sought) }\end{array}$ & $\begin{array}{l}\text { BENEFITS } \\
\text { - Funders bring large-scale litigation experience and } \\
\text { significant funding for support, which can help achieve } \\
\text { "equality of arms" } \\
\text { CHALLENGES } \\
\text { - Power imbalances between funder and community } \\
\text { - The need to generate a financial return limits } \\
\text { applicability; some important litigation outcomes } \\
\text { (seeking injunctions, judicial review, etc.) not applicable }\end{array}$ \\
\hline
\end{tabular}




\section{TABLE 2: OTHER SOLUTIONS FOR INCREASING FUNDING OR REDUCING COSTS}

\begin{tabular}{|c|c|c|c|}
\hline Financing solution & \begin{tabular}{|l} 
Funding \\
source
\end{tabular} & $\begin{array}{l}\text { Investment-related processes that could be } \\
\text { covered }\end{array}$ & Main benefits and challenges \\
\hline $\begin{array}{l}\text { Crowd funding, } \\
\text { using online } \\
\text { platforms to secure } \\
\text { donations from } \\
\text { individuals }\end{array}$ & Citizen donors & $\begin{array}{l}\text { - Monitoring and fact-finding } \\
\text { - Litigation } \\
\text { - Potentially others }\end{array}$ & $\begin{array}{l}\text { BENEFITS } \\
\text { - Accesses new funding sources, with few restrictions on } \\
\text { how money can be spent } \\
\text { CHALLENGES } \\
\text { - Likely to only raise small amounts of money }\end{array}$ \\
\hline $\begin{array}{l}\text { Profits from social } \\
\text { enterprise, which } \\
\text { can be used to pay } \\
\text { for community } \\
\text { support }\end{array}$ & $\begin{array}{l}\text { Community or } \\
\text { CSO-driven } \\
\text { social } \\
\text { enterprise }\end{array}$ & $\begin{array}{l}\text { - Preparing internally before engaging with a company } \\
\text { - Influencing due diligence and planning } \\
\text { - Consultation and initial interactions with a company } \\
\text { - Negotiating (or re-negotiating) a contract with a } \\
\text { - Mompany } \\
\text { - Dispute resolution } \\
\text { - Litigation } \\
\text { - Project closure and rehabilitation }\end{array}$ & $\begin{array}{l}\text { BENEFITS } \\
\text { - Accesses new funding sources, with few restrictions on } \\
\text { how money can be spent } \\
\text { CHALLENGES } \\
\text { - The amount of revenue generated will depend on how } \\
\text { much time and effort is put into it, and on the degree to } \\
\text { which any needed expertise can be accessed } \\
\text { - Running a new enterprise brings its own financial risks, } \\
\text { such as insolvency }\end{array}$ \\
\hline $\begin{array}{l}\text { Affordable user fees } \\
\text { or in-kind services } \\
\text { paid or provided by } \\
\text { community } \\
\text { members to support } \\
\text { providers }\end{array}$ & $\begin{array}{l}\text { Community } \\
\text { members }\end{array}$ & $\begin{array}{l}\text { - Preparing internally before engaging with a company } \\
\text { - Influencing due diligence and planning } \\
\text { - Consultation and initial interactions with a company } \\
\text { - Negotiating (or re-negotiating) a contract with a } \\
\text { - Mompany } \\
\text { - Dispute resolution } \\
\text { - Litigation } \\
\text { - Project closure and rehabilitation }\end{array}$ & $\begin{array}{l}\text { BENEFITS } \\
\text { - Encourages community buy-in for the support given } \\
\text { - Reduces dependence on outside funding sources } \\
\text { CHALLENGES } \\
\text { - Not likely to generate sufficient funds to meet all of } \\
\text { community's support needs }\end{array}$ \\
\hline $\begin{array}{l}\text { Contingency and } \\
\text { uplift fees, which } \\
\text { render fees, } \\
\text { calculated according } \\
\text { to a pre-agreed } \\
\text { formula, only } \\
\text { payable if the } \\
\text { outcome of the } \\
\text { support is successful }\end{array}$ & $\begin{array}{l}\text { Support } \\
\text { provider }\end{array}$ & $\begin{array}{l}\text { - Negotiating (or re-negotiating) a contract with a } \\
\text { company (provided it is likely to include significant } \\
\text { sharing of revenues with the community) } \\
\text { - Litigation (only damages claims where a large } \\
\text { amount of money is sought) }\end{array}$ & $\begin{array}{l}\text { BENEFITS } \\
\text { - No payments required up front } \\
\text { - Community only pays when support achieves } \\
\text { SUCcessful outcomes } \\
\text { CHALLENGES } \\
\text { - Legally prohibited in some jurisdictions } \\
\text { - Creates conflicting incentives for support provider } \\
\text { - Need to generate a financial return limits applicability; } \\
\text { some important contractual outcomes (contracts not } \\
\text { featuring extensive financial benefits) and litigation } \\
\text { outcomes (seeking injunctions, judicial review, etc.) } \\
\text { not applicable }\end{array}$ \\
\hline $\begin{array}{l}\text { Fee shifting, which } \\
\text { entitles successful } \\
\text { community } \\
\text { claimants to have } \\
\text { their support costs } \\
\text { paid by the losing } \\
\text { counter party }\end{array}$ & \begin{tabular}{|l|} 
The \\
community's \\
counter-party \\
in a court case
\end{tabular} & - Litigation & $\begin{array}{l}\text { BENEFITS } \\
\text { - Community does not pay for successful cases } \\
\text { - Making the unsuccessful counter-party pay for costs } \\
\text { can incentivize the avoidance and early resolution of } \\
\text { community grievances } \\
\text { CHALLENGES } \\
\text { - Fee shifting is often limited to "public interest"/ } \\
\text { constitutional cases brought against governments }\end{array}$ \\
\hline
\end{tabular}




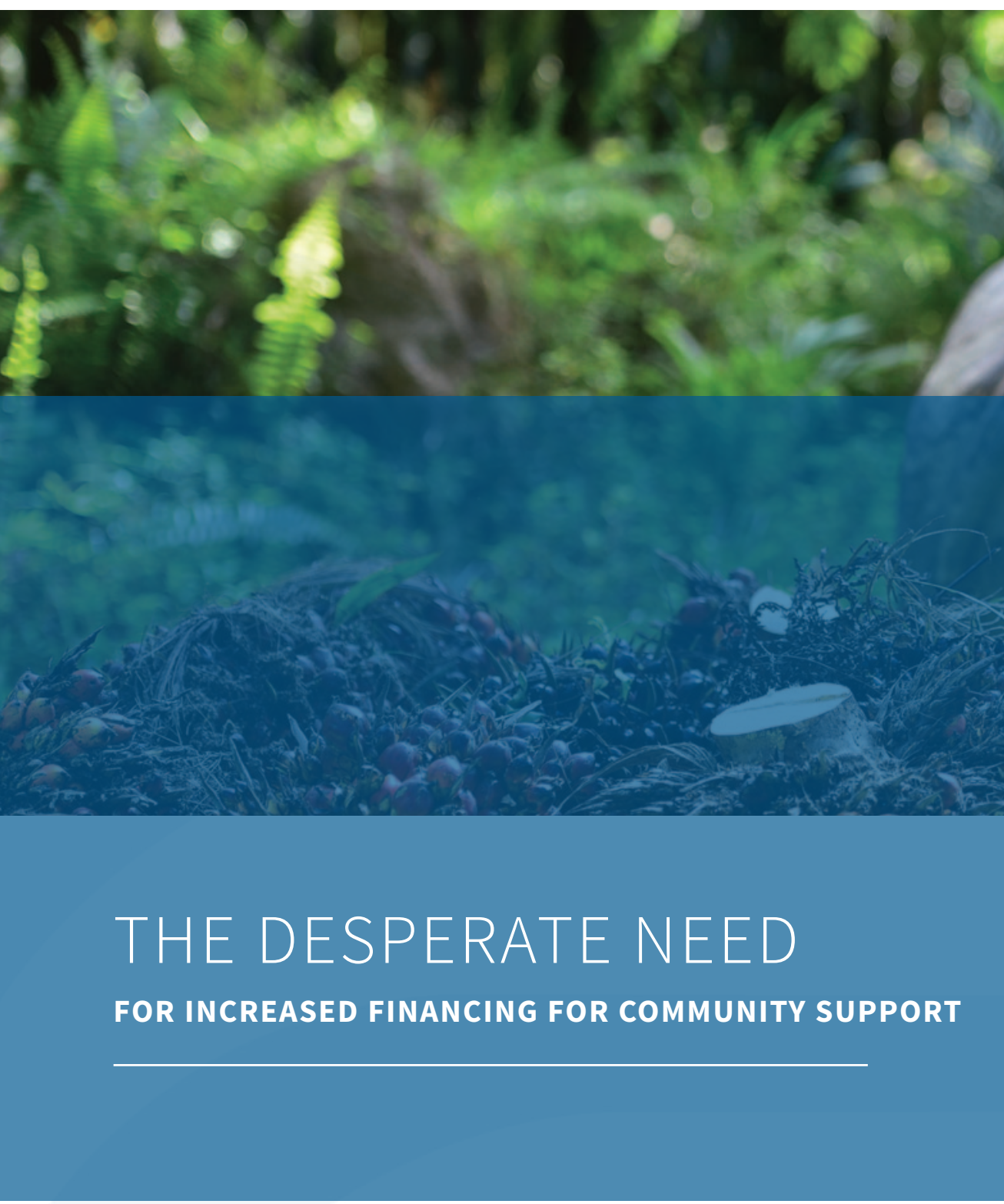

Land investments, such as investments in agriculture and forestry projects, continue to place intense pressure on community lands and resources in the global south. Companies, often navigating complex legal frameworks, generally can afford the legal or other technical support they require for their investments. In stark contrast, the communities potentially affected by such investments frequently struggle to access the support they need to protect their interests, in large part because they cannot afford it. ${ }^{1}$ As a result, many communities are at risk. Without legal support in securing their resource rights or when negotiating a lease with an incoming company, they risk losing access to critical land and resources that sustain their livelihoods and provide social, cultural, or spiritual meaning. Without adequate support during consultations, monitoring, or the pursuit of urgent court orders to stop breaches of law or contract, communities risk suffering human rights violations. Without support negotiating a benefit agreement, they risk missed opportunities to secure enforceable development outcomes from the 
investment. The frequent inability of communities to access needed support is not only devastating for communities: it can also result in conflict and challenges that are damaging for companies, host governments, and other actors.

Adequately financed legal and technical support-from the moment a land investment is proposed until well after it has concluded-can help communities avoid and mitigate risks. This support can bolster community efforts to: make due diligence and planning processes more consultative; influence decisionmaking regarding proposed investments; assert customary rights; negotiate a balanced agreement with an incoming company; monitor company operations; resolve grievances or disagreements with the company and/or government; or hold them to account through litigation or other processes.

The need for community support in the context of investment is well recognized. The former UN Special Rapporteur on indigenous peoples ${ }^{2}$ and the Inter-American Commission on Human Rights, ${ }^{3}$ for example, have emphasized the importance of community support for addressing power imbalances and facilitating informed community decision-making during consultations. A former World Bank staffer made similar observations in the context of community-company contract negotiations. ${ }^{4}$ As these experts have recognized, communities that lack sufficient legal and technical support during these early stages of potential land investments may have fewer strategies available to proactively defend their human rights and livelihoods, and to assert their priorities for sustainable development.

When communities cannot access appropriate support, other actors-including companies, their financiers, and host governments-can also experience negative impacts. A lack of support increases the risk of community grievances, stemming from issues such as mismatched expectations, inadequate consultation, or onerous or unenforceable community-company contracts. ${ }^{5}$ Community grievances and social unrest can open the door to disputes and conflicts that result in significant human rights violations, ${ }^{6}$ poisoned community-company relations, and/or disrupted business operations. Conflicts and consequent project delays create significant financial and opportunity costsfor companies seeking to generate profits, governments wishing to earn tax revenues, and community members hoping for associated development opportunities. One study estimated that delays stemming from tenure disputes can cost an agribusiness as much as $\$ 101$ million in foregone revenue. ${ }^{7}$ Such disputes have also led to outright project failure, such as a Tanzanian sugar plantation, which received a $\$ 52$ million investment but was abandoned before its first day of production. ${ }^{8}$

The risks faced by communities and companies, while different in nature, evidence a striking need for innovative approaches to financing community support, and to increase the impact of existing funding. While the largely unmet need for general legal aid services around the world has been extensively researched, less attention has been given to the obstacles communities face in securing legal and technical support in the context of investment. The investment context creates specific and pressing support needs for communities, but it also presents possibilities for companies and other private sector actors to act as novel funding sources (albeit while introducing new challenges). This report evaluates a range of financing solutions for community support that can be adapted to different scales or focused on specific geographies or sectors. Given the potential costs of ignoring this financing gap, this report is as relevant for a company's business managers as for its community relations team; similarly, it is as germane for host governments and DFIs as for affected communities, and the CSOs supporting them.

Where, then, might the capital needed to finance legal and technical support be located? What challenges would be introduced by resorting to new funding sources or approaches, and how can those challenges be addressed? How can funding, once secured, be most effectively used to meet the support needs of communities? This report explores these questions. A follow-up paper will offer concrete guidance on one of the options discussed in this report: basket funds.

BOX 1: WHAT IS "LEGAL AND TECHNICAL SUPPORT"?

Legal and technical support to communities includes formal legal assistance, as well as other forms of technical assistance or advice that communities may need when preparing for potential investment or engaging in processes related to a proposed investment. Such support may be provided by CSOs, lawyers, paralegals, and experts in business, economics, science, and impact assessments, among many other fields. 


\section{THE CURRENT STATE OF FINANCING}

Although the current number of communities globally that need support relating to land investments is unknown, ${ }^{10}$ representatives that we interviewed from the private sector, DFIs, academia, and civil society regularly noted that current funding for community support runs short of what is needed. The Roundtable for Sustainable Palm Oil's 2015 guide on free, prior and informed consent acknowledges that most communities lack support and, as a consequence, often do not understand their rights when approached by a company; the guide concludes that there is a clear need for improved legal and technical support to communities, while asking where the funding for such support would come from. ${ }^{11}$

One civil society representative we interviewed noted that their organization had worked with local CSOs to support between 200 and 300 communities in Indonesia, and estimated that the number of Indonesian communities needing support in the context of land investments could be several tens of thousands. While many different organizations already provide support to communities there, the representative strongly doubted that traditional donor funding would be made available to finance legal and technical support for this number of communities. ${ }^{12}$ While these observations focus on Indonesia, they help to illustrate the vast scale of funding that is potentially needed globally.

Donors often fund non-profit CSOs, including those with legal or technical expertise that can be deployed to assist communities. Yet these CSOs almost never have the financial or human resources to meet the support needs of every affected community within their sphere of operations. Donors may also finance external experts in some circumstances; for example, donors funding community-led litigation may cover the cost of independent lawyers and expert witnesses in addition to financing the CSO that is the community's primary point of contact. Yet the financial reserves of such donors can only extend so far.

Communities can also obtain legal and technical support through other sources, although each also brings its own challenges. For instance:

- Lawyers and experts sometimes provide legal and technical assistance on a pro bono (free) basis. However, the demand for such services far outweighs the supply. Moreover, the need for long-term engagement limits how many pro bono matters experts can take on. In addition, many corporate law firms decline pro bono requests where the counter-party is a company that may be a current or future source of paid work..$^{13}$
- University- and donor-funded law clinics deploy lawyersupervised students to support communities. These clinics, however, can often only sustainably support a limited number of clients, especially when based overseas.

- Some companies directly finance legal and technical support for communities. Yet this introduces the risk of perceived or actual undue influence of the company over the community or support provider. Because of this risk, some support providers also will refuse to take money offered by companies.

- Some community members themselves pay for support. But their financial reserves are often extremely small, limiting which support providers they can procure after paying for other life- or livelihood-sustaining services or activities.

While these sources each crucially help to fill support gaps that communities face, together they still remain woefully inadequate to meet the vast needs of communities affected by land investments. Additional financing models are therefore needed.

As shortfalls in funding for community support have become more apparent, the need to find additional solutions to finance legal and technical support has been highlighted by a range of different actors, including academics, ${ }^{14}$ researchers, ${ }^{15}$ civil society actors, ${ }^{16}$ indigenous communities, ${ }^{17}$ international organizations, ${ }^{18}$ and multi-stakeholder groups ${ }^{19}$ and networks ${ }^{20}$ that include companies, DFIs, and industry bodies. The need for improved financing solutions is also evidenced by a number of pioneering efforts to develop new approaches. At least two organizations have attempted to develop basket funds to meet community legal and/or technical support needs. ${ }^{21}$ Others are experimenting with impact investment, third party litigation funding, and crowd funding to help increase the amount of money available for community legal and technical support.

\section{WHAT TYPES OF SUPPORT DO COMMUNITIES NEED MORE OF?}

Communities who are, or who stand to be, affected by land investments often require the services of CSOs, paralegals, organizers, non-legal experts, lawyers, or other actors. These support providers can help communities meaningfully participate in, or otherwise protect their interests during, different investment-related processes. 
Support providers can help communities to carry out any of the following:
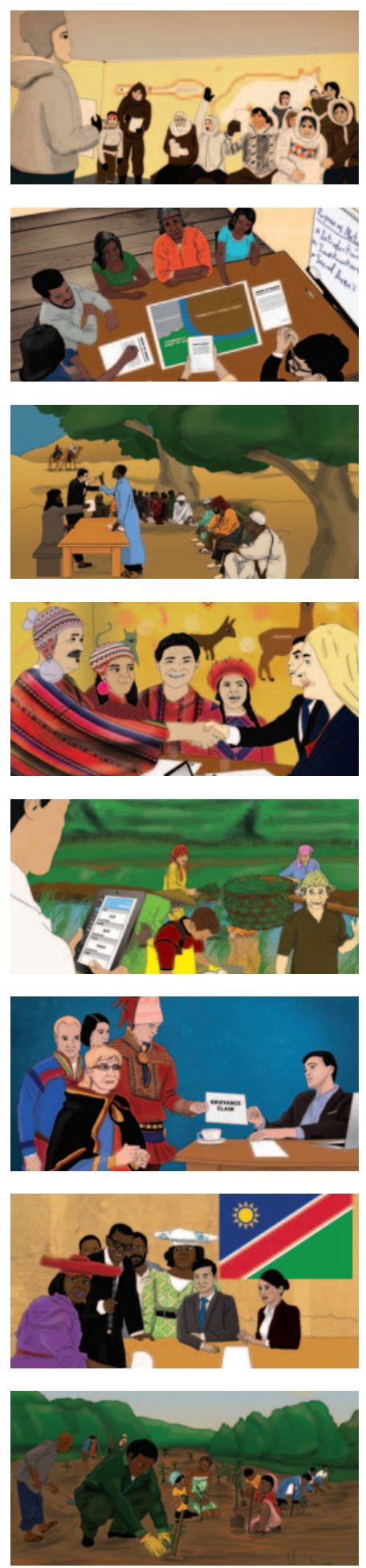

- Ensuring responsible project closure and rehabilitation. This includes holding the company and host government to their obligations, if they have any, to implement closure plans and/or rehabilitate and return the land to the community when a project winds down or is terminated.
Certain financing models may be better suited to different processes. Nonetheless, an approach that covers community support needs both before a project begins (preparation, consultation, negotiation) and afterwards (monitoring, dispute resolution, project closure) reinforces and enhances the impact of any support given. For instance, legal support for contract negotiations may be undermined if the community cannot later access support to hold the company to its obligations through monitoring and dispute resolution. 


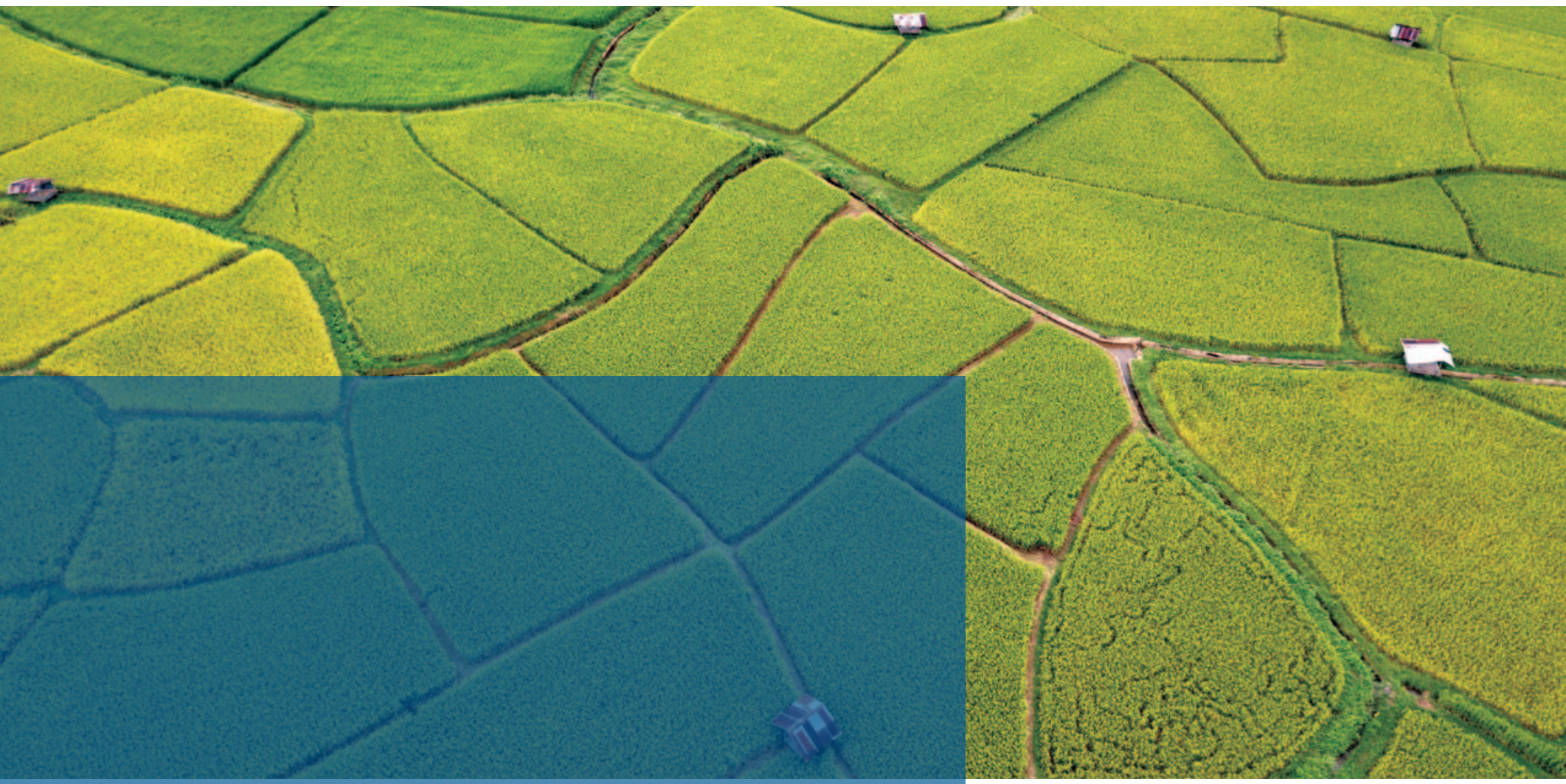

\section{FINANCING} SOLUTIONS

Rice field, Thailand.

(c) oBebee/shutterstock

While governments, donors, the private sector, and civil society all have a role to play, their specific interests in promoting financing solutions align and diverge at different points. Stakeholders' opportunities to take concrete action will also vary. These factors have implications for the types of initiatives that any specific constellation of actors may try, as well as the parameters of those initiatives. For instance, the shared interest of community advocates and companies in reducing potential conflict in a specific area might result in an initiative that draws primarily from private sector funding sources to finance support for negotiations and for resolving grievances, but that does not finance litigation.

Any financing initiative should therefore identify which activities would be covered. Designing a needs-based initiative might entail identifying the ideal scope to address documented needs, and then matching that scope to the incentives and challenges of potential contributors of funding. In some cases, a proactive funding source may instead be the starting point, and may state for which processes it would be willing to finance community support. 


\section{GOVERNMENT MARSHALING}

Host governments-especially democratic ones-are an intuitive source of funding for community legal and technical support, given their human rights obligations, SDG commitments, and ability to collect revenue from citizens and corporations. This section explores how governments can generate funding beyond existing tax revenue; ${ }^{25}$ in doing so, governments can seek to increase the support available to communities without diverting finite public resources from other important public services. ${ }^{26}$

\section{Why would governments want to marshal finance?}

Host governments, and the many entities and actors they comprise, may have a number of reasons for seeking new ways to pay for community support.

- Low- and middle-income countries usually struggle to provide basic legal services for all citizens, ${ }^{27}$ not just communities affected by investment. Marshaling new sources of funding can thus increase the government's available financial resources to address this vital need in the context of land investments.

- Financing support for communities for processes such as consultations, negotiations, or non-judicial dispute resolution can help companies and communities establish and maintain stable relationships. Such stability can lead to more productive and conflict-free investments that produce anticipated benefits for host countries, such as revenues, and help governments to attract the most responsible companies.

- Community support for monitoring could also potentially complement host government efforts to monitor investments, as supported communities could more effectively observe, and promptly notify the government of, any issues of importance that arise. ${ }^{28}$

- Governments could fund community support for additional processes, including those aimed at resolving conflict and/or addressing rights violations, to productively respond to political pressure they face, including from social movements or CSOs voicing community grievances, international partners calling for the advancement of SDG 16, or even companies wishing to resolve existing, and avoid future, community conflict.

- Funding services can help governments demonstrate their commitment to addressing public outcry concerning investment or justice gaps, helping to maintain political stability, avoid popular revolts, ${ }^{29}$ and/or regain citizen trust following a period of armed conflict or fragility. ${ }^{30}$

\section{Taxes, fees, and penalties}

The arrival of a company will often increase a local community's need for legal and technical support. To address this increased need, host governments can use taxes, fees, and penalties to collect additional money from companies to finance community support. Taxes and fees involve charging a company for certain activities, such as: applications for, or the granting of, permits or licenses; the commencement of the project; or one or more preestablished thresholds of production, revenue, or profits generated by the company. (Taxes on specific processes that marshal revenue for a specific purpose are sometimes called "parafiscal taxes.") Penalties, on the other hand, can apply when companies contravene certain rules, such as breaches of law or concession contracts, and would be payable in addition to any liability for damages or loss that such breaches cause. The rates

\section{EXAMPLE: TAXING COMPANIES TO FINANCE COMMUNITY CONSULTATION IN CANADA}

The Aboriginal Consultation Levy Act, ${ }^{31}$ a law in Alberta, Canada, sought to impose a levy on resource companies that would be paid to a fund that could be accessed by First Nations and other aboriginal communities to develop their capacity for, and to pay relevant costs relating to, consultation processes. Details about how much revenue was to be collected and how grants would be made were to be included in Regulations, which were never drafted. ${ }^{32}$ The initiative was repealed, however, in part because of First Nations' concerns regarding strict time limits set out in the Act for consultation processes and the lack of recourse for First Nations if the government-run consultation office determined that no consultation was required in a particular case. ${ }^{33}$ This illustrates the importance of adequately incorporating community perspectives into the design of government marshaling strategies, and of other initiatives, that aim to increase the amount of money available for community support. 


\section{EXAMPLE: IMPOSING PENALTIES PER COMPLAINT LODGED IN AUSTRALIA}

The Australian Telecommunications Industry Ombudsman ${ }^{34}$ establishes a consumer complaints process that is financed exclusively by penalties charged to the member telecommunications company that is the subject of each complaint. Companies pay a "volume fee" (based on the overall proportion of complaints made against them in a given year) and an operating cost fee that goes towards the Ombudsman's operational costs such as staff salaries. In addition to generating additional financing, this scheme is believed to also motivate companies to resolve complaints before they reach the Ombudsman. ${ }^{35}$ The financial feasibility of adapting a similar penalties-based approach to an initiative to finance community support would depend on the number of grievances that might be anticipated in a country or region, and the political feasibility of imposing penalty rates that are high enough to generate sufficient money.

\section{PROPOSAL: FINANCING LEGAL SERVICES THROUGH COMPANY FEES IN SIERRA LEONE}

Sierra Leone's 2013 Draft Guidelines For Sustainable Agricultural And Bioenergy Investment call for the establishment of a Community Justice Fund. ${ }^{36} \mathrm{Companies,} \mathrm{after} \mathrm{registering} \mathrm{with} \mathrm{the} \mathrm{country's} \mathrm{investment} \mathrm{promotion} \mathrm{agency,} \mathrm{would} \mathrm{periodically} \mathrm{pay} \mathrm{a}$ mandatory fee calculated to cover the average monthly cost of a Sierra Leonian lawyer. Companies would then submit a consultation plan detailing how they will seek to obtain the free, prior and informed consent of communities potentially affected by the proposed investment. Companies would then carry out consultations and impact assessments, before negotiating leases with community land owners and a memorandum of understanding and agreement with the government. ${ }^{37}$ The fund would be administered by the District Council, with oversight by the Human Rights Commission of Sierra Leone. Money would be allocated to pay a lawyer chosen by the community from a network of justice organizations and practitioners supported by the Human Rights Commission. The lawyer would provide "community justice services, including legal advice, assistance, representation and [...] education in the negotiation process" with the company. ${ }^{38}$ Proponents of "large and huge scale impact projects" would pay the fee monthly, while smaller projects would pay the same fee but on a less frequent basis (thus paying proportionately less overall).

The policy, while still in draft form, appears to have benefitted from strong civil society collaboration and guidance; the emphasis on financing legal support may also be legitimized by Sierra Leone's constitutional recognition of the right to legal aid. ${ }^{39}$

Sierra Leone's National Land Policy also sets out that the government shall take measures to implement a legal assistance fund for "legal and paralegal assistance to communities, land owners and land users in negotiation with potential large scale land investors," as a strategy to implement its goal of creating an enabling environment to attract responsible and rights respecting investment. ${ }^{40}$ This legal assistance fund has not yet been established, and it is not clear whether the government will employ the same ideas that have been outlined for financing the abovementioned Community Justice Fund.

of taxes, fees, and/or penalties should be calibrated to balance the goal of revenue generation with considerations of what is politically feasible. By marshaling funds specifically for community support, a government would create a type of basket fund, which is a fund with multiple contributing entities; Section "2. Basket funds," below, is therefore also relevant to this approach.

\section{Trust fund interest and other moneys collected from legal professional practice}

Another strategy for government marshaling of funding for community support is to collect interest on lawyers' trust accounts ("IOLTA") or other payments related to legal professional practice. In many countries, client money is often 
EXAMPLE: COLLECTING INTEREST ON TRUST ACCOUNTS TO FINANCE LAW CLINICS IN SOUTHERN AFRICA

In Namibia and South Africa, interest earned on client moneys that lawyers hold in trust is allocated to a fidelity fund. ${ }^{45}$ In certain circumstances in Namibia and South Africa, some of that money can be allocated to education or research in legal professional practice ${ }^{46}$ In South Africa, some fidelity fund money also has been used to finance law clinics, ${ }^{47}$ providing a glimpse of how fidelity funds could be used to help finance community legal support.

held in trust by lawyers in anticipation of fees and expenses. ${ }^{41}$ Some governments collect the interest that these trust accounts generate and use it to increase funding available for legal aid. This approach could be used to help finance investment-related community legal support, although the money raised would likely be allocated to a broader category of legal aid funding, given the lack of a direct connection to land investments. Marshaling IOLTA in a global south context may not generate enough revenue by itself to finance a large amount of legal support; this strategy may therefore be better deployed to complement, and contribute to the financial sustainability of, other financing initiatives.

IOLTA is a large source of legal aid funding in Australia and Canada, among other countries. In Botswana, Namibia, South Africa, and Zimbabwe, IOLTA is collected for "fidelity funds," which compensate clients who suffer loss because of their lawyers' illicit or dishonest conduct. ${ }^{42}$ Aside from IOLTA, other moneys also can be collected from legal professional practice. Pursuant to a recently introduced initiative in Singapore, for example, unclaimed client money held in trust by lawyers will now be allocated to a fund intended to supplement pro bono services. ${ }^{43}$ In Malaysia and Barbados, fidelity funds and some legal aid services are financed by annual contributions from members of bar associations. ${ }^{44}$

\section{Social impact bonds}

Governments can also marshal funding from impact investors through using social impact bonds. These involve investors advancing money for community support in exchange for payouts from the government (or other outcome payers) if preagreed goals are achieved. Social impact bonds are discussed further in "3. Impact investment," below.

\section{BASKET FUNDS}

In this report, a basket fund refers to a collection of money from multiple sources to be spent on legal and technical support for communities. Basket funds can be administered by an existing third party entity or a newly established trust or foundation with an arm's length relationship to companies and communities. Basket funds can move beyond traditional philanthropic and aid donors, potentially securing money from companies, commodity buyers and traders, and DFls, among other actors. Basket funds that draw on a large number of funding sources minimize the risk of dramatic reductions in financial contributions. Such risks can be further minimized by securing commitments for contributions to be made on a regular basis.

This report focuses on basket funds that provide grants for external support providers, rather than employing in-house support providers. ${ }^{48}$ Grant-making reduces operating costs by requiring fewer in-house staff, ${ }^{49}$ and allows more flexibility for community members to choose support providers with appropriate skills and experience. Such an arrangement can also more easily leverage existing CSOs that have the trust of, and ongoing relationships with, the community.

A basket fund offers the promise of leveraging money from companies and other actors in a way that minimizes their actual or perceived influence over communities and support providers. Such influence is minimized in two ways. First, obtaining money from multiple sources with differing interests and in a balanced proportion can "dilute" any funding source's ability to use its contribution as a point of leverage over a community..$^{50}$ The risk of undue influence may diminish as each source's contribution becomes a smaller portion of the total money raised, although basket funds receiving money from multiple entities with similar interests, such as a company and its financier for an investment project, may not achieve this dilution effect. Secondly, having a third party entity administer 


\section{FIGURE 1: ONE POSSIBLE ITERATION OF A BASKET FUND}

Funding can be sourced from various entities. One option is to source regular funding from companies and buyers of their products. Foundations and donors could provide initial "seed" funding and/or ongoing funding to help diversify the basket fund's funding sources. DFls, commercial banks, MSIs, industry bodies and/or host governments could also assist, including by encouraging or requiring companies within their sphere of influence to contribute funding, or potentially by contributing funding themselves.
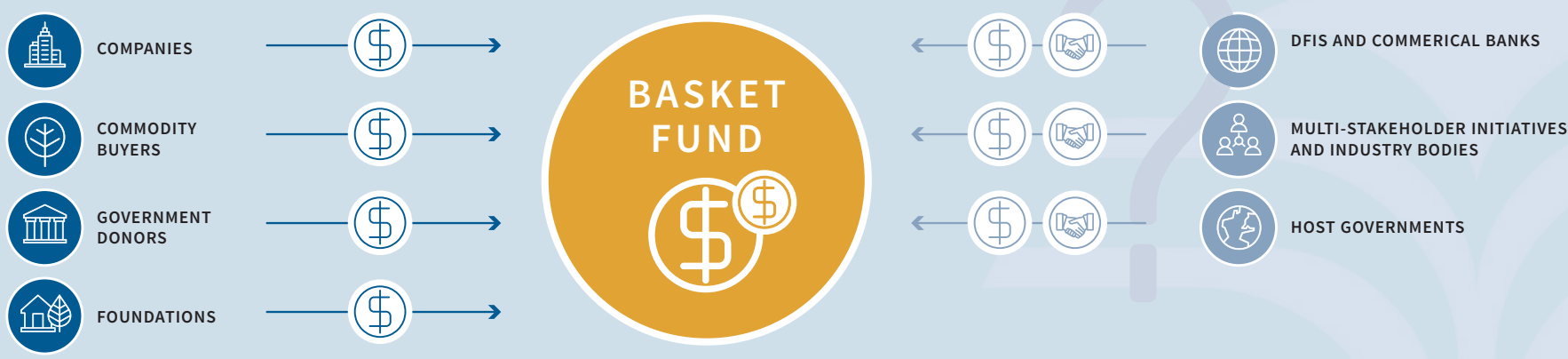

and pay out money can help protect against such influence by excluding funding sources from the determination of who will receive money, and under which conditions. Design choices, such as the extent to which contributions and contributors are kept confidential (discussed below), can further disassociate money paid out from any specific contributor.

\section{Why would different actors want to contribute to a basket fund?}

Companies might contribute to a basket fund for several reasons.

- Contributing to a basket fund can help companies understand and incorporate community perspectives, work towards obtaining the community's "social license to operate," and avoid or resolve costly conflict..$^{51}$ Adequate financing of community support for consultations and negotiations can improve community-company communication, help align expectations about future decision-making and the project's potential impacts, and encourage potentially lasting consensus. ${ }^{52}$ In addition, financing support for dispute resolution may help resolve existing community grievances before they lead to litigation. ${ }^{53}$

- Contributing to a basket fund may increase the potential for stable community-company relations by enabling communities to become strong counter parties. Basket funds can help communities access the support they need without worrying that doing so increases the company's influence. Basket funds are therefore a desirable alternative to direct, project-specific company funding, which may create such concerns. ${ }^{54}$

- Basket funds that receive contributions from multiple companies would also enable companies seeking to implement responsible investments to do so on a more level playing field with any competitor companies who participate. ${ }^{55}$

Commodity buyers and sellers, such as food and beverage companies and commodity traders, may be motivated to contribute to a basket fund to avoid negative impacts and related community grievances that may harm their reputation. ${ }^{56}$ Financing community support may also help buyers to fulfill commitments to sustainability or good governance. ${ }^{57}$

DFIs and commercial financiers might be motivated to contribute to, or otherwise participate in the establishment of, a basket fund, ${ }^{58}$ as a strategy for increasing compliance with finance-linked performance standards. Increased funding for community support (through initiatives like basket funds) could improve a client company's compliance with performance standards or other loan conditions in various ways. ${ }^{59}$ For instance, support to an Indigenous community during consultations may help a company to obtain that community's 
free, prior and informed consent, as required under the IFC's Performance Standards and the Equator Principles. ${ }^{60} \mathrm{~A}$ meaningful consent process might also help the company to better apprehend and avoid adverse social or environmental impacts, minimizing the likelihood of community grievances and conflict. Fewer grievances and less conflict would reduce the demand on finance-linked grievance mechanisms, protect the financier's reputation, and avoid disruptions to company operations, which could imperil the company's ability to generate profits. Adequately supported communities can also more effectively monitor, and notify relevant financial institutions, if a company breaches relevant standards.

Multi-stakeholder initiatives with fee-paying company members may also be interested in participating in the establishment of a basket fund as a means of furthering their internal sustainability principles. For instance, MSI standards and requirements that companies obtain the free, prior and informed consent of affected communities ${ }^{61}$ may be more likely to be met where communities can access appropriate support to help them understand available information and make informed decisions when engaging with the company. ${ }^{62}$ If such initiatives do not have sufficient resources to make a financial contribution towards a basket fund themselves, they may still play a useful role by encouraging or even requiring member companies to make financial contributions to a relevant basket fund.

Donors, ${ }^{63}$ including philanthropic foundations and bilateral and multilateral aid organizations, that are interested in ensuring that communities have access to relevant support may be interested in contributing funding, especially to help establish a basket fund that has a clear strategy for becoming financially sustainable and not overly dependent on continued donor funding. ${ }^{64}$ While not the only model for donor participation, donors could contribute initial "seed" money while also financing the development of a basket fund's objectives, scope, and structure.
Helping to pay for these initial activities could help avoid actual or perceived undue influence from well-resourced private sector actors while the ground rules are set, thereby minimizing the risks of such influence throughout the basket fund's operation.

\section{Initial considerations and design questions for basket funds}

Basket funds can take many forms, depending on their scale and the actors involved in their design. Aside from the initial considerations, discussed in "Governance," below, that apply to financing initiatives generally, considerations specific to basket funds include:

- Scope. The basket fund's scope will affect the entities willing to provide funding; for instance, focusing on specific commodities or production areas may help to attract buyers or traders of such commodities, commodity-specific MSIs, or donors with interests in supporting communities in relevant production areas.

- Avoiding undue influence. Steps should be taken to address potential concerns that basket funds financed by corporate actors would introduce the risk of conflicts of interest or undue influence. ${ }^{65}$ Specific approaches to reduce these concerns, each with their own costs or challenges, include: routing the money through a trusted third party entity; sourcing funding from a wide variety of sources; and sourcing money from company foundations, rather than from company project budget lines to help de-emphasize the link between the money and a company's specific investment project. ${ }^{66}$

- Transparency. A basket fund may be established with varying degrees of transparency. It could function as a "black box" fund, in which funding sources and amounts are kept confidential to reduce each contributor's

\section{PROPOSAL: PEACENEXUS COMPANY-COMMUNITY TRUST FUND, MOROCCO}

In 2015, PeaceNexus, a foundation focusing on peace-building in conflict-affected contexts, proposed establishing a basket fund that would source funding mostly from companies, while still seeking to build trust between all stakeholders. The fund's goals were to "strengthen and support community-company dialogue and the ability of stakeholders to engage and influence decisionmaking," especially in fragile extractive sector contexts. ${ }^{74}$ Peace Nexus sought to pilot this approach at the national level in Morocco, ${ }^{75}$ and committed to finance the secretariat that would collect and pay out money for the first year. To date, however, the fund is yet to become operational. One interviewee opined that the large number of relevant stakeholders for a nationallevel fund created a degree of political complexity that had stymied the fund's establishment. ${ }^{76}$ 
connection to, and potential influence over, the basket fund, the recipient community, and/or their support providers. Alternatively, the basket fund could disclose who contributes money but not the amounts that each contributed; this might allow stakeholders to understand who is participating, while minimizing the ability of any specific entity to use its contribution as a point of leverage. Finally, the fund could function as a "glass box" fund, where all contributions (and, potentially, contributors) are transparently disclosed; this approach can help address suspicions of secrecy by allowing stakeholders to track amounts paid into the basket fund. ${ }^{67}$ Determining how much information to disclose regarding amounts paid out and/or the recipients also requires careful consideration. Full disclosure could help to detect any misappropriation of money but could also stoke resentment among neighboring communities. It may also be strategically disadvantageous to disclose a community's support budget to any counter-party. A more suitable protection against misappropriation could be to arrange for regular, independent audits.

- Role of government. For non-governmental initiatives, host governments might still play a productive role, depending on the degree to which they are trusted by local communities and other stakeholders. ${ }^{68}$ Host government actors can potentially, among other things, participate in multi-stakeholder oversight committees, offer vital knowledge about the local context, and help to sensitize incoming companies of the need to contribute money for community support.

\section{EXAMPLE: KUMACAYA}

Kumacaya is a basket fund initiative that collects money from multiple private sector actors for specific monitoring or research jobs that Kumacaya designs before tendering them to in-country CSOs. Kumacaya is currently based at the Earthworm Foundation (formerly TFT), an initiative with fee-paying member companies, which include companies that carry out relevant agricultural and forestry projects and "end user" buyers of agricultural and forestry products. The sources of funding for each job are kept confidential so that CSOs are not at risk of being influenced or discouraged from applying. In many cases, the identities of successful CSO bidders are also kept confidential. Each job targets specific production areas where multiple producers operate and multiple buyers source commodities; this helps to attract funding from multiple, often competing, companies. Examples of jobs advertised include researching the conditions of oil palm mill and plantation workers in East Kalimantan, Indonesia, and measuring the quality of free, prior and informed consent processes that have taken place in parts of Liberia. ${ }^{69}$

\section{EXAMPLE: RSPO DSF TRUST FUND 70}

The Roundtable on Sustainable Palm Oil (RSPO) - a global MSI with members including oil palm plantation companies, processors and traders, manufacturers and retailers of palm oil products, financial institutions, and CSOs-established a trust fund to finance support for participants in its Dispute Settlement Facility (DSF), which uses mediation to facilitate the settlement of disputes. The trust fund is financed by a portion of annual member fees, which range from $€ 100-2,000 .^{71}$ The fund was established in 2009 to meet concerns about how affected community members would finance any capacity building or technical support needed when participating in a DSF processes. As of December 2018, however, no money had been paid out from the fund to participants in DSF processes. Two interviewees suggested that this was due at least in part to a lack of awareness of the fund's existence; ${ }^{72}$ one of those interviewees also asserted that a CSO assisting a community had been told that it was not eligible to access the fund. ${ }^{73}$ 
The Samdhana Institute, an Indonesian non-profit organization that provides small grants to grassroots initiatives and organizations, ran a trust fund from 2011-2013 to advise project-affected communities in Sumatra, Indonesia. Money from the trust was provided to CSOs working with specific communities to pay lawyers, resource economists, or other experts supporting communities. The trust started with philanthropic funding and planned to transition to a "blind trust" with multi-party funding to increase the scale of communities that could be reached. In 2013, however, donor funding concluded, and the transition to a blind trust could not be realized.

The intention had been for Samdhana to expand the trust by seeking financial and in-kind contributions from all relevant stakeholders and to manage financial contributions in a blind trust. The "blind trust" element was to be designed to avoid a direct link between any company's financial contribution to the trust and any moneys paid for support to a particular community. Agribusiness and forestry companies that had made human rights commitments and/or had experienced conflicts with communities would provide funding; donors would finance the trust's operational costs; local government would be asked to provide experts and venues for meetings; and communities would be asked to make "in kind" contributions such as providing additional venues and food for meetings. Applications to the trust would be made by CSOs who had already entered into an agreement with affected communities that sought advice and support. The blind trust would contract with successful applicant CSOs, who would then be accountable for procuring the relevant technical support for the community.

A foundation in Indonesia is currently researching how a blind trust with similar purposes and financing strategies as Samdhana's planned blind trust could be implemented.

\section{IMPACT INVESTING}

Impact investments could be used to secure funding to pay for community support in situations where the support is expected to achieve a pre-agreed goal that would enable and/or justify the investors to be paid back. Impact investments differ from mainstream investments (such as loans or purchasing shares) in that they are designed to generate both a measurable positive social and/or environmental impact and a financial return. ${ }^{78}$ The intent to generate a financial return in turn distinguishes impact investments from philanthropy or grant making.

Because impact investments are profit-seeking, they are only feasible for financing community support in the rare contexts where there is an opportunity for significant compensation. Specifically, impact investment could be used to finance: the negotiation of benefit agreements that are expected to generate very large amounts of revenue for communities; litigation where the community is seeking a very large sum of damages or compensation; or social impact bonds, where a government, donor, or other actor is willing to ultimately finance the legal support, as an "outcome payer."
How the impact investment is structured will affect who is responsible for paying impact investors. In the case of social impact bonds (see Box 2, below), commitments for repayment are secured from governments, donors, DFIs or other entities willing to act as outcome payers who compensate investors upon the achievement of pre-agreed goals. For other impact investment models, communities themselves could be bound to pay back the funding; for instance, the RTC Impact Fund (discussed below) proposes to finance support to communities wishing to negotiate benefit agreements, on the understanding that if the community secures sufficient money through the agreement, it will gradually pay back the money provided, potentially with interest or at a premium.

Financial returns for impact investors can vary. Some investments may be structured to only return some or all of the money invested ("capital preservation") and others may produce below-market interest or profits ("concessionary investments"). Others, still, might seek to produce risk-adjusted market-rate returns, although such returns may be extremely unlikely in the case of impact investments to finance community support. 


\section{FIGURE 2: THE IMPACT INVESTING SPECTRUM}

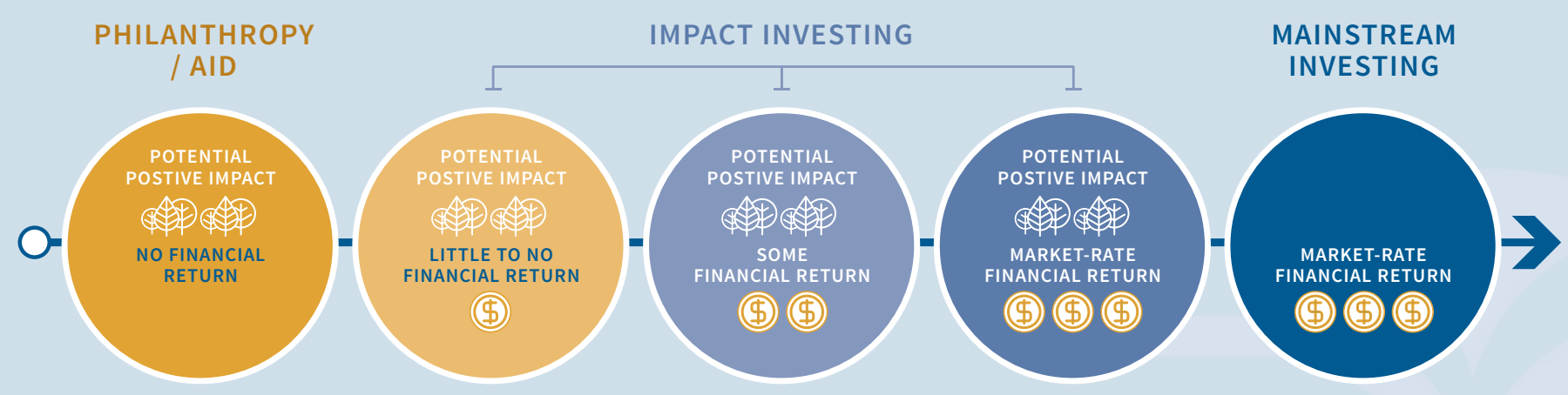

Adapted from: netimpact.org/careers/impact-investing

Any initiative seeking to finance community support through impact investing should be designed to avoid exploitative levels of investor profits that would ultimately be paid by communities. For instance, if an impact investment is structured as a loan with a high compounding interest rate, communities could find themselves locked into a cycle of inescapable debt, as has happened with some microfinance interventions. ${ }^{79}$ Similarly, an arrangement for impact investors to be paid a percentage of any benefit-sharing revenues might not leave enough funds for the community to pursue vital livelihood strategies or to adjust for the project's negative impacts. Impact investment arrangements should therefore carefully define and limit when, if ever, the community would be required to pay. Hybrid or blended approaches to repayments, such as sharing repayment obligations between a community and donor, or having a government guarantee a community's repayment obligations, may help to avoid exploitative arrangements and make impact investments viable.

Whether impact investment should be used to finance community support in a specific case will depend on various factors. These include:

- The goal that triggers repayment. Impact investments usually define the social and/or environmental impacts they seek to achieve. Yet the outcomes of different processes or

\section{BOX 2: WHAT ARE SOCIAL IMPACT BONDS?}

A social impact bond (SIB) is a financial instrument that functions on a "payment by results" basis. ${ }^{80}$ If an SIB were used to finance community support, an impact investor would pay money to an intermediary, which would disburse the money to one or more support providers. ${ }^{81}$ If the community support achieved pre-agreed goals, the "outcome payer"-this could be the government, a donor, or another entity-would be obliged to pay an agreed premium to the investor. SIBs' payment-by-results model makes them most appropriate where a demonstrable public saving or desirable development impact will be secured by achieving the pre-agreed goal and when the outcome payer wants to avoid the risk of paying for an initiative that might not achieve desired impacts. ${ }^{82}$ For example, an SIB in the United Kingdom saw investors finance rehabilitation services for ex-prisoners from Peterborough jail; these services were intended to reduce recidivism, thereby minimizing the government's expenditure on prosecutions and imprisonment. The pre-agreed goal, a 7.5\% reduction in recidivism, was achieved, and the government paid back the investors with interest. ${ }^{83}$ If pre-agreed goals are not achieved, as occurred when a similar SIB failed to reduce youth recidivism at New York City's Rikers Island prison by $10 \%$, the government pays back nothing or proportionally reduces the repayment of money to the investor. ${ }^{84}$ 
community actions are not always predictable. A tension may emerge between impact investors focusing on achieving a financial return (who would aim to set a low bar for repayment) and the entities responsible for repaying (who may prefer to give the community sufficient autonomy to determine its priorities and strategies, so that the support empowers rather than constrains community members). For example, a goal focused on achieving a target number of negotiated contracts could be too simplistic; it might create perverse incentives or simply not be met, given that some communities may ultimately decide not to negotiate with a company. Having different classes of impact investors, including "first loss" partners who absorb the risk when full financial returns are not achieved, may help in finding arrangements that are acceptable both to investors and to those responsible for repaying. Donors willing to act as a first loss partner can help catalyze impact investments by encouraging additional investors.

- Availability of data. For a host government or donor to issue an impact bond, they would have to view improved community support as producing a social good worth paying for. To determine this, the government or donor may need to generate new data to determine the various public costs of not making support available to community members. ${ }^{85}$ Impact investors also need data to develop a risk profile for the proposed investment in community legal support and understand its likely outcomes, both in terms of social impact and financial return. ${ }^{86}$ Investors will also rely on a mechanism to monitor their investments and determine whether the pre-agreed goal has been achieved.

- Financial considerations affecting viability. Impact investments often require significant amounts of regularly updated data, increasing their transactional and operational costs. These costs, and the likely costs of hiring support providers, will therefore need to be compared to the amounts of money that supported communities can expect to gain or the savings or other beneficial outcomes such financing support may produce. For impact investments relying on communities for repayment, due consideration must also be given to the community's financial needs for basic survival and livelihood generation in the short, medium, and long term. In practice, such impact investments may therefore only be feasible where a community seeks a sufficiently large amount of money (through negotiated benefit sharing arrangements or court-ordered damages awards). Specifically, the expected amount of money would have to be large enough that the community could repay impact investors while retaining enough money to meet its needs and compensate for any actual or anticipated adverse impacts. ${ }^{87}$

\section{Why might impact investors be willing to finance community support?}

Impact investors may only be willing to finance community support if they can adequately assess the likelihood of producing both a measurable positive social or environmental impact and a financial return. This will depend on whether sufficient data exists to assess the risk and expected return of the investment, a cost-effective financial instrument is available to facilitate the provision of funding, and arrangements are in place to robustly monitor and report on the impacts of funding in each case. Impact investors interested in market-rate returns may not be interested in, or appropriate for, financing community support. 88

\section{Why might donors be willing to participate?}

Foundations and other donors are increasingly seeking out and designing innovative impact investment opportunities to deploy their capital toward mission. In some cases, this includes making a financial return that can be re-deployed toward further investment. Foundations could play one of two roles in an impact investment to finance community support; either could be critical in unlocking additional private capital:

- As an outcome payer. Foundations could use their grantmaking funds to act as an outcome payer for an SIB; doing so would allow them to avoid paying for unsuccessful interventions and limit their grant-making to interventions that achieve the intended impact. 89

- As an investor. Foundations could use their endowment capital to make a mission-related investment ("MRI"). An MRI could be used to finance community support provided the investment: (a) furthers the foundation's mission, and (b) meets a "prudent investment" test. This test may not be met if the foundation is seeding untested financial products or providing first-loss capital to attract non-philanthropic investors. ${ }^{90}$ Alternatively, a foundation could invest money reserved for grant-making to finance community support as a program-related investment ("PRI") to pursue a concessionary investment or catalyze co-investment. In the U.S., this is permissible provided the investment: (a) has the primary purpose of furthering any of the foundation's exempt (charitable) purposes, and (b) does not have the significant purpose of producing income or the appreciation of property. ${ }^{91}$ 


\section{PROPOSAL: THE RTC IMPACT FUND}

The RTC Impact Fund proposes a portfolio of investments in legal and technical support for communities affected by natural resource projects in the global south to enable communities to negotiate benefit agreements with companies ${ }^{93}$ Capital for each investment would likely come first from foundations and other donors willing to take on greater risk for lesser returns, in the form of programrelated investments. Other impact investors may later be encouraged to join, especially if donor investors are willing to assume first loss risk. ${ }^{94}$ Recipient communities would pay the funding back over time by allocating a percentage of the revenue they earn from the benefit agreements they have signed. The transactional costs associated with each loan are not yet known but are expected to be considerable, given the time and resources needed to understand the local context and to work with community members before a loan can be contemplated. If the company only has to share revenues with the community when it starts production or generates a profit, the community may not receive any revenues for several years, increasing the likely timeline for repayment.

One question the RTC Impact Fund may face is determining what the consequences would be if the community changes course after receiving funding for legal support. To avoid a community feeling pressured to sacrifice its priorities in order to quickly reach an agreement and start earning revenue, RTC Impact Fund is considering using non-recourse loans and is seeking to attract investors more concerned with achieving a positive social impact than with financial returns..$^{95}$ The RTC Impact Fund model may also only be applicable to sectors or commodities that are especially profitable, such as large-scale extractive industry projects. Industries with smaller profit margins, such as agriculture and forestry, may result in much smaller payments to communities, limiting the amount of money that communities would be able to pay back.

\section{Would communities and their support providers be willing to participate?}

While communities and CSOs may be willing to consider any new forms of funding for support, many may be hesitant to work with for-profit investors. Especially in contexts where a profit motive is regarded as introducing the same dynamics that led to the inequality and injustices that many affected communities already experience, ${ }^{92}$ communities may be more open to impact investments that de-emphasize the need for a market-rate return to investors. The involvement of donors or host governments as outcome payers might also make communities more comfortable with participating.

Communities may also be more likely to participate if impact investments are made as non-recourse loans, allowing flexibility for changes in community strategies. Non-recourse loans would extinguish the right of impact investors to be repaid if the anticipated activity (such as negotiation or litigation) is unsuccessful in producing adequate financial gains for the community or is abandoned before gains are made. To attract impact investors, a non-recourse loan could be complemented by having an external guarantor, such as a DFI or donor, which would pay the investor in such circumstances.

\section{THIRD PARTY FUNDING}

Third party funding is occasionally used to finance community support-specifically, legal support to litigate claims for monetary damages or compensation. No instances of third party funding for community legal support for contract negotiations or other processes were identified in this research. Third party litigation funders typically agree to finance the costs of litigation and any indemnity (such as for costs orders against the client if it loses) in exchange for a financial interest in the outcome of the case. This interest could be a share of the money awarded to the claimant, a multiple of the amount the financier provided, or a combination of the two, ${ }^{96}$ depending on what was agreed beforehand. Third party funding is usually "non-recourse," meaning that if the case is unsuccessful, the funder is not repaid for the money it has spent.

Before agreeing to work with third party funders, communities need to carefully consider the desirability of working with a forprofit partner. On the one hand, funders can offer financial and strategic might to inexperienced claimants, which can reduce power imbalances between an affected community and its well-resourced company counter-party. Indeed, litigating against companies may require significant amounts of money, especially where a company's defense strategy includes tactics to increase the length of a case, and hence the amount of expensive legal services needed by a community claimant.97 
On the other hand, third party funding itself can also introduce power imbalances-between financiers, who are typically wellresourced and experienced, and community claimants, who may be contemplating litigation for the first time. Funders view cases that they finance as investments, and thus may wish to oversee how the litigation is conducted; whether or not this is permitted under domestic law varies in different jurisdictions ${ }^{98}$ Funders also do not typically have any legal duties to the financed community, ${ }^{99}$ which is in stark contrast to the fiduciary obligations for profit maximization that funders owe to their shareholders. This introduces the risk that some funders may interpose themselves in the lawyer-client relationship and seek to direct or influence decisions in ways that are not in the community's interests. Having an experienced and trusted legal team can help to minimize power imbalances with the funder, and guard against an unfair funding agreement. Host governments also have an important role to play in establishing legal frameworks that both facilitate and adequately regulate litigation funding.

Whether third party funding is a viable or desirable option in a particular context-for communities and for funders-will depend upon various considerations. These include:

- The funder's criteria. Litigation funders often have criteria for financing a case, which can include: strong prospects of winning; the defendant having the resources to meet any judgment for damages; and the claimant having a credible strategy for enforcing a successful judgment. To ensure financial feasibility, funders often require that the amount of funding requested and/or the amount of anticipated damages be above a minimum amount, or that the legal costs to be financed be proportionate to the claim amount or the work required for the case itself.100

- The jurisdiction's legal framework. An initial hurdle is whether third party funding is legally permissible in the relevant jurisdiction. ${ }^{101} \mathrm{~A}$ strong legal regime to regulate the funder-client relationship should also be a prerequisite for communities contemplating third party funding. Communities should check whether there are laws that help to avoid exploitative arrangements. Such laws include requirements that a judge approve any agreement for financing legal support before a case begins, as occurs in Ontario, Canada. ${ }^{102}$ Appropriate laws will require judges to make sure that:

- The claimants' lawyers are appropriately qualified to conduct the litigation.

- The funding agreement does not give the funder an unacceptable degree of influence over how litigation is conducted and whether or not to accept a settlement offer.

- The share payable to the funder, if the claimant wins an award for damages, accords with best practice.

- The terms of any settlement that the parties reach would produce an equitable result. ${ }^{103}$

In circumstances where no such laws exist, communities and CSOs working with them risk entering into an arrangement that may not prioritize their interests.

\section{EXAMPLE: ECUADORIAN COMMUNITIES LITIGATE AGAINST TEXACO/CHEVRON}

In addition to a contingency fee arrangement, litigation brought by Ecuadorian peasants and Indigenous people against Texaco/Chevron for environmental pollution was financed in part through third party funders, including an individual investor and a boutique hedge fund. While these third party funders became involved as the litigation's scope and complexity expanded, they withdrew their investments shortly afterwards, as Chevron sued one of the community's lawyers for racketeering. ${ }^{104}$

\section{EXAMPLE: INDONESIAN SEAWEED FARMERS LITIGATE AGAINST PTTEP AUSTRALIA}

Harbour Litigation Funding is currently financing a suit brought in Australia by over 13,000 Indonesian seaweed farmers against a Thai oil company, PTTEP Australia (Ashmore Cartier) Pty Ltd. The suit claims that a 70-day-long oil spill in the Timor Sea in 2009 caused the farmers a collective loss of earnings of over AUD 200 million. ${ }^{105}$ 


\section{BOX 3: LEGAL INSURANCE}

Legal insurance involves an insurer providing access to legal support, when needed, to insured persons who regularly pay premiums (these are calculated based on the likelihood that legal support will be needed and on the cost of that support). Microinsurance for legal needs can entitle insured persons access to a limited range of legal support, such as advice hotlines and basic document review services, in exchange for smaller premium payments. ${ }^{106}$ While legal insurance has been used for a number of legal issues, it remains relatively untested in the context of land investments.

Although micro-insurance could theoretically be used to finance a limited range of anticipated or potential legal services in the context of land investment, it would have to overcome many challenges. Rural community members in the global south generally do not have much excess income to purchase insurance. ${ }^{107}$ Community members also may not be motivated to pay for insurance before companies arrive. And, even if community members did purchase insurance, their claims could be denied by insurers who exploit grey areas or misunderstandings about exclusions and coverage in policies. ${ }^{108}$ In other cases, a lack of appropriate regulation may enable insurers to operate without sufficient capital, increasing the risk that insolvency causes them to default without honoring valid claims. ${ }^{109}$ Lawyers financed by legal insurers also may be regarded as serving both the insured and the insurer; 110 this creates the risk that the lawyer's professional obligations to their insured client may be undermined by a need to maintain a positive relationship with the insurer, which may be the source of future work.

One example of legal microinsurance is Legalwise, which provides insurance to individuals in South Africa for civil, criminal, and labor law matters. Legalwise uses hotlines with trained staff to answer basic legal questions and outsources litigation to external lawyers, who usually provide support at significantly reduced rates. Its most basic plan has a monthly premium of around USD $\$ 7$, which affords the insured coverage for legal costs up to around $\$ 7,000$ per matter. ${ }^{111}$ This premium attracts clients in the "mid to lower" income levels, ${ }^{112}$ but such an amount would likely not be accessible by affected communities living in extreme poverty.

- Rule of law in the jurisdiction. Given the importance of legal frameworks, third party funding may only be advisable for communities where a country's government and judicial system are likely to fairly and efficiently enforce laws regulating third party financing. Indeed, third party funders may also be reluctant to finance legal claims in countries without a strong rule of law, where the prospect of success might be weakened by unpredictable host state courts or where significant costs and challenges associated with enforcing any successful judgment may exist.

\section{DIRECT COMPANY FUNDING}

Companies, given their access to capital and interest in ensuring a stable local context for their operations, may wish to directly finance community support to facilitate consultations, ${ }^{113}$ negotiations ${ }^{114}$ or even monitoring ${ }^{115}$ for a specific project. Such an approach does not comprehensively increase community access to support providers, ${ }^{116}$ however, and makes each community reliant on the good will of a company in a particular case, which will decide how much money it will provide, when, and on what conditions. Direct payments by a company also raise risks that the support provider may be influenced by the company, and/or that the community will not trust the support provider. Such an approach should therefore be considered with extreme caution.

In the rare case that a community_or a CSO working to support a community-wishes to accept direct company funding, steps should be taken to minimize the risk that the company will obtain a new form of leverage over the community. Such steps can include:

- Agreeing on clear written rules concerning amounts payable, timelines, and acceptable uses of the money.

- Having an impartial third party receive and disburse company money according to those rules.

- Giving communities full autonomy in choosing support providers.

- Where appropriate, front-loading payment of the estimated amount of money needed.

- In the case of consultation and negotiation processes, 


\section{EXAMPLE: FUNDING PREPARATION AND NEGOTIATION IN AUSTRALIA}

In Australia, Argyle Diamonds Limited (owned by Rio Tinto) paid more than AUD 2 million over several years to a land council working on behalf of Aboriginal native title holders. The land council spent this money on preparatory processes (such as an ethnography of traditional owners, hydrological consultants, and social impact assessment consultants) and negotiation activities (including for drafting memoranda of understanding and contracts). ${ }^{118}$

\section{EXAMPLE: FINANCING CSO ENVIRONMENTAL MONITORING IN THE U.S.}

Lundin's (formerly Rio Tinto's) Eagle Mine Community Environmental Monitoring Program (CEMP) requires the company to make payments every six months to a foundation, which disburses money to a CSO that is charged with monitoring the mining project once an oversight board approves the CSO's work plan. The CEMP does not, however, provide funding to community members to decide on their monitoring needs and is thus not an example of the financing of legal or technical support. The agreement establishing the CEMP was between the company and the CSO, reducing the ability for community members to participate in the design of the arrangement. And while the original program included an oversight role for community members, a 2016 amendment of the agreement removed that role. ${ }^{119}$

signing a written agreement that the community's acceptance of the money is not evidence of community consent to the investment project, and that the community has no obligation to repay the money even if it eventually withholds its consent or declines to transfer rights to its land, where relevant.

- Having trusted intermediaries helping communities to understand that by accepting the money, and the support provided through it, they are not required to take (or avoid taking) any particular actions.

Even with these precautions, the receipt of such money could exert subtle pressure on community members who may feel indebted to the company, thereby undermining the community's ability to freely decide how it wishes to proceed. Communities who are organized, empowered, informed, supported by CSOs, and/or based in countries whose laws, courts, and government acknowledge and protect community land rights will thus be most suited to avoiding such pressure.

Careful attention also needs to be given to which entity will receive the money (see "3. Linking the financing initiative with communities and support providers," below). If the company wishes to pay the money to a support provider directly, this may limit the amount of support providers willing to accept such funding, as some (but not all) ${ }^{117}$ might refuse to accept company funding.

\section{OTHER SOLUTIONS FOR FINANCING SUPPORT OR REDUCING COSTS}

Other options exist both for raising smaller amounts of money and for reducing the cost of support. These will usually need to be combined with other financing sources and strategies to meet a community's support needs.

\subsection{Crowd funding}

Communities, or the CSOs working with them, can use crowd funding to raise money to cover either direct support to communities or the costs that accompany such support. Crowd funding typically involves using fundraising websites ${ }^{120}$ to secure cash donations from large numbers of individuals for specific campaigns. People who contribute money typically do not gain any financial interest in the legal matter or activity that is financed.

Successful crowd funding campaigns are able to reach a wide audience and present a compelling case for making a donation. They may appeal to people's emotions or reassure potential contributors by showing an organization's record of good governance, transparency, and effectiveness. ${ }^{121}$ Some 
crowd funding websites also regularly provide quantitative data to demonstrate how people's money is being spent. ${ }^{122}$ Reaching potential contributors in wealthier countries and aligning crowd funding campaigns with popular social movements can also help to increase money raised. ${ }^{123}$

Different processes or actions could feasibly be the basis for a crowd funding campaign, provided that there is a demonstrable and compelling reason that funded support will lead to a positive outcome for the community. For instance, a crowd funding campaign to finance a court case that a community wishes to pursue would need to demonstrate why having legal or technical support would help the community to achieve a positive outcome, such as court-ordered compensation for rights violations, or the preservation or restoration of their livelihoods or dignity.

Crowd funding is often done on a project- or organizationspecific basis; this scope helps to craft clear narratives and explain how the money will be used. Where strong narratives exist around specific issues or developments, crowd funding for initiatives with a broader scope may be possible. For instance, the Time's Up Fund drew on a growing concern about sexual harassment to crowd fund for a nation-wide Legal Defense Fund (see Box 4).

\subsection{Profits from social enterprises and side businesses}

Communities, or support providers, can use money earned through social enterprises to subsidize the costs of support. One example is BRAC's legal aid clinics in Bangladesh: 73\% of the clinics' total costs are covered by revenue from BRAC's social enterprise businesses, which include selling dairy and animal products and providing agricultural services, such as refrigerated food storage. ${ }^{125}$ Other support providers earn revenues from services more closely linked to their daily work; for instance, Cambodia's Community Legal Education Center rents out its conference room and offers for-fee training programs on different legal topics. ${ }^{126}$
Social enterprises can help develop steady long-term revenue streams, ${ }^{127}$ as opposed to more volatile financial contributions from donors or other sources, whose priorities may change over time. They can thus contribute to an initiative's long-term financial sustainability, even if other complementary funding sources will also be needed.

\subsection{Affordable user fees / provision of in-kind services to support provider}

While community members will usually not be able to cover the full costs of support providers, pooling resources may make paying for needed support providers more feasible. ${ }^{128}$ Alternatively, economies of scale may be achieved if multiple community members pay a paralegal to carry out certain services on their behalf, such as obtaining documents from far away courts or administrative offices, thus saving time and reducing costs associated with travel. ${ }^{129}$ The Deme So initiative in Mali follows this model, and community members also perform inkind work for paralegals, such as cleaning, cooking, or feeding cattle. ${ }^{130}$ Affordable user fees and in-kind payments can help to encourage community buy-in and engagement with the services provided. ${ }^{131}$ Community contributions could also be added into a basket fund and might help to "dilute" the perceived influence of other contributors of funding, such as companies.

\subsection{Contingency fees}

In some jurisdictions, lawyers are permitted to offer contingency fees or uplift fees to clients, effectively making the lawyer the source of funding. ${ }^{132}$ Contingency arrangements usually operate on the basis that the client pays no money up front for the legal services, but if the client successfully secures a "contingency-generating event," such as a payment of damages in a court case, the lawyer is entitled to an agreedupon payment, which could be the lawyer's fees as usually calculated or a percentage of the money secured by the client. If the contingency-generating event is not achieved, the lawyer

\section{EXAMPLE: CROWD FUNDING FOR LITIGATION}

The International Senior Lawyers Project raised over USD \$7,000 for incidental costs, such as local travel and printing costs, relating to a UK lawsuit brought on behalf of 200 farmers in Cambodia against Tate \& Lyle Sugars. ${ }^{124}$ The farmers were represented by pro bono lawyers in the UK, US, and Cambodia. 
is not paid for the work done. Uplift fees operate on a similar basis, but calculate payment based on a percentage or multiple of the lawyer's usual fee for the work performed. Contingency and uplift fees will not be applicable to instances where the community is not expected to secure a large amount of money, such as when it seeks a declaration or injunction from a Court.

Contingency and uplift fees might be used to finance community support for contract negotiations with a company and, potentially, litigation. Such fees will only be useful, however, when the negotiation or litigation could secure a sufficiently large payment to the community. Some jurisdictions prohibit contingency or uplift fees in litigation because such fees give lawyers a direct financial interest in the case, which can compromise lawyers' independence and change the lawyer-client relationship. ${ }^{133}$ The use of such fees for transactional services in commercial settings is commonboth for lawyers ${ }^{134}$ and for non-legal professionals, whose fee arrangements are often less strictly regulated. Contingency and uplift fees-whether for litigation or contract negotiations-should be considered with caution and only used where a sufficient degree of trust between the community and support provider exists, and preferably where a community can easily seek review of a contingency or uplift arrangement by a judge or trusted legal expert, if needed.

\subsection{Fee recovery and costs protections}

Host government lawmakers and courts can develop laws that shield affected communities and other public interest claimants from the expensive nature of litigation. While eligible "public interest" cases are often limited to specific cases brought against the government, ${ }^{136}$ greater protection would be afforded to community claimants if such entitlements extended to relevant cases against companies.

- Before a case begins, courts could consider awarding advance funding of community claimants' costs by the respondent government or company where: the community cannot afford the litigation; the case has prima facie merits (meaning that initial evidence the community presents, without being questioned by the other side, seems to prove the case); and the case is of public importance. ${ }^{137}$

- If a community claimant is successful, fee-shifting rules could entitle claimants to secure fee awards, payable by their counter-party, to cover their lawyers' costs. Even in cases where lawyers act on a pro bono or low cost basis, fee awards for public interest litigation in some jurisdictions are calculated by multiplying the number of hours a lawyer spends on a case by the market rate for a private lawyer with comparable experience; a less complicated model is to have a set hourly rate that applies to all cases. ${ }^{138}$

- If a community claimant is unsuccessful, the law in some places may allow a court to avoid ordering the community to pay the other side's legal costs. This may be possible where the court considers it to have been in the public interest to have heard the case. In some cases, courts even make a fee awards in favor of unsuccessful claimants, where the case involves testing fundamental constitutional principles against a government respondent. ${ }^{139}$ 


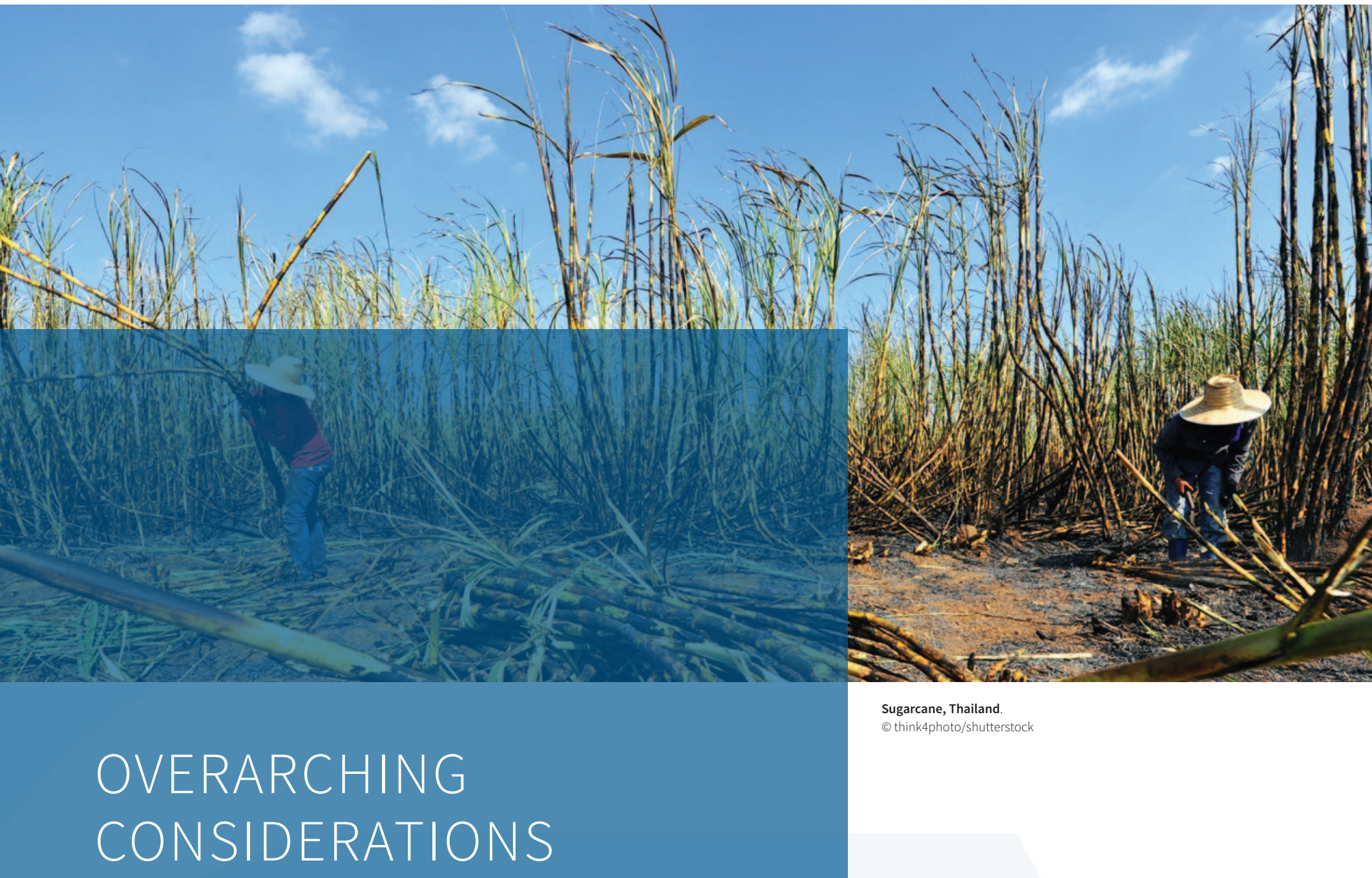

Stakeholders seeking to develop a financing initiative must consider a range of issues that have implications for the initiative's sustainability and design. We focus here on three sets of considerations: those relating to the amount of money needed; those concerning efficiency, effectiveness, and sustainability; and those addressing the links between the initiative, communities, and support providers. 


\section{THE AMOUNT OF MONEY NEEDED}

\section{Community preferences and needs}

Anticipating the preferences of target communities for specific types of support providers can help to predict the likely amount of money required. For instance, some communities may prefer a local lawyer who understands their context, while others may prefer support from outsiders who, while potentially more expensive, may be perceived as less likely to be influenced by powerful local stakeholders. ${ }^{140}$ Some communities may also be less interested in working with specific types of support providers-such as lawyers-at all. For instance, in Liberia, many people distrust the country's legal system and thus may be less interested in engaging in formal legal processes, such as litigation. ${ }^{141}$

In addition to community preferences, financing initiatives could also respond to unrecognized community needs. For example, a community that obtains support before decisions about a proposed investment are made can be empowered to influence decision-making processes in ways that protect community rights and livelihoods. Yet communities often will not seek support until something goes wrong. ${ }^{142}$ Awareness raising and trainings can empower communities to seek out support at a much earlier stage. Costs associated with any awareness raising and trainings that might be needed should also be factored into estimates of the amount of money required.

\section{Scope}

Another factor affecting a financing initiative's costs is its potential scope. For instance, an initiative could cover a specific area, country, or continental region, or a specific commodity or industry. Adjustments to scope will affect the number of communities requiring support, affecting the amount of money needed.

\section{Data to estimate costs and feasibility}

Reviewing relevant information concerning support needs and costs -in light of the initiative's desired focus, scope, and objectives-can help to predict the likely overall amount of money needed for a specific initiative. Yet the generation of data may be another cost. Useful data might include:

- Within the parameters of the desired scope, the numbers of actual or anticipated investment projects and of affected communities that would likely require financing assistance, as well as other information to help determine the likelihood that such support will be needed. Legal needs surveys, if available, can provide useful insight into the legal support needs of specific populations. ${ }^{143}$
- The likely costs, availability, capacity, and effectiveness of types of support that communities might use, and the likely duration of such support, which may be gleaned from sources including courts, legal aid organizations, bar councils, and support providers themselves.

Data can also help different actors understand the feasibility of generating a financial return or of otherwise defraying the costs of financing support:

- Information about household incomes in target areas, for example, can help to reveal whether models based on user fees or legal insurance are feasible.

- Information about the likely financial outcomes for supported communities (how likely is it that the community will earn revenue from a benefit agreement or secure damages from a court case?) will help determine whether initiatives reliant on the generation of a financial return, such as impact investments or thirdparty funding, are feasible.

- Data about political, economic, and governance riskssuch as the risk of corruption, fraud or theft, project failure, insolvency, market price fluctuation, or an inability to enforce a successful judgment-can help impact investors, third party funders, and lawyers acting on a contingency or uplift basis to determine whether or not their financing strategy is feasible.

\section{EFFICIENCY, EFFECTIVENESS, AND SUSTAINABILITY}

\section{Keeping costs of support low}

In addition to increasing financing available to communities, financing initiatives can also try to reduce costs of support. Strategies to keep the costs of support low include:

- "Unbundling" or separating the legal and technical needs of communities into tasks for which higher and lower cost support (and hence financing) is needed, as well as tasks that can be done by community members themselves. 144

- Using low-cost services that charge fees that community members can afford for basic procedural tasks, such as obtaining official documents.

- Using or encouraging pro bono or low cost support ${ }^{145}$ (or contingency fees), and capping specific amounts of money available for specific tasks (with discretionary processes for additional funding, as needed). See, for example, Box 4, below. 
BOX 4: FINANCING LOW-COST LEGAL SUPPORT - THE TIME'S UP LEGAL DEFENSE FUND

The Time's Up Legal Defense Fund, established in the wake of growing awareness of workplace sexual harassment in the United States, collects donations and then pays for (or defrays the costs of) very specific types of U.S.-based legal support relating to workplace sexual harassment and retaliation. To maximize cost efficiency, the fund requires participating support providerswho apply for funding - to provide a free initial consultation to their client. It also imposes monetary caps for different services (for complainants bringing civil claims, investigation is capped at USD $\$ 3,000$, pre-filing work and negotiation at $\$ 10,000$, trial litigation at $\$ 100,000$, and appeals at $\$ 50,000)$. ${ }^{148}$ The fund has also obtained a significant amount of pro bono and low-cost support ${ }^{149}$ and participating attorneys commit to repaying the fund if they successfully obtain an award for legal costs.

- Relatedly, crowd and/or expert sourcing_submitting a call for assistance with specific legal or technical tasks ${ }^{146}$ through online platforms or existing networks-may help a community to minimize the tasks for which it needs to pay for support. However, there would be no guarantee of the independence or expertise of those who answer such calls for assistance. Potentially relevant tasks include reviewing technical documents, researching the company's reputation and conduct in previous projects, and conducting legal research. ${ }^{147}$ Most tasks would need to be reviewed by the community's support provider.

Confidentiality concerns, whether strategic or raised by the company, might limit when crowd sourcing will be feasible.

\section{Financial sustainability}

Any financing initiative needs to be financially sustainable so that it can continue to provide funding in the short, medium, and long term.

One strategy to help extend the lifespan of a financing initiative is to divert a percentage of all money raised into a reserve fund. Sometimes called "endowment funds," 150 reserve funds are invested to generate additional returns, thereby increasing the total amount of money in the fund over time. For instance, a fund established for communities affected by the Yanacocha mine in Peru reserves over 25\% of its annual income to be reinvested. ${ }^{151}$ One drawback of reserve funds is they reduce the budget for spending, at least in the beginning, ${ }^{152}$ which might be challenging if a limited amount of money has been raised. In addition, reserve funds may fail to grow or even shrink if investments do not perform well. Financing initiatives that rely on endowments without regularly generating additional money may also simply run out of money. ${ }^{153}$
In addition to those discussed in "6. Other solutions for financing support or reducing costs," above, strategies for raising additional and ongoing funding for an initiative will vary depending on the approach taken. Common considerations include:

- Frequency of financial contributions. Requiring money to be paid regularly, such as annually, or securing commitments to regular payments outside of mandatory schemes, can help to maintain the lifespan of the financing initiative. For example, Sierra Leone's 2013 Draft Guidelines on Sustainable Agricultural and Bioenergy Investment include the establishment of a Community Justice Fund, financed by companies, who would periodically pay a mandatory fee. Obtaining oneoff contributions, on the other hand, will require regular fundraising efforts. An exception might be if one-off contributions are large enough to cover all relevant future support needs; for example, if the support is intended for a short period of time, such as during the closure phase of a project.

- The strength of commitments to provide funding. An initiative's financial sustainability can be undermined if some actors fail to pay. The chances of such failure might depend on how robust each actor's commitment to pay is. For instance, legal requirements to pay fees in exchange for licenses, and contractual obligations to provide future funding, will generally be more reliable than purely voluntary commitments to provide funding. Another potential source of obligation could be to require companies to pay into a relevant financing initiative as a condition of MSI membership or DFI investment in the company's investment project.

- Ensuring that financing commitments can be met. If a community is granted funding for a specific process (for 
instance, contract negotiations) and if the money is paid incrementally, the estimated total amount of money that the community will need for the entire process should be set aside. This can help to avoid running out of money for the support before a matter concludes, even if the initiative eventually runs out of money.

\section{Scope (again) and political and contextual challenges}

In addition to affecting the amount of money required, scope can affect the feasibility and appropriateness of different types of financing initiatives. For instance, a host government is unlikely to be interested in marshaling revenue to finance support for communities outside of its jurisdiction, which could mean that government marshaling is less feasible for initiatives with a global scope (unless pursued by home governments, whose outward investing companies may operate in multiple countries). A relevant impact investment mechanism, on the other hand, could apply to a range of countries, provided they have the preconditions required to establish a workable investment. Initiatives built for the national (or subnational or local) levels can also be better adapted to the specific local context, including local laws, support provider culture, and community conditions. Sectoror commodity-specific initiatives, however, which may benefit from important entry and leverage points, may be able to apply across countries. ${ }^{154}$

Scope can affect an initiative's political complexity. Nationallevel initiatives, for example, may require the buy-in of a large number of stakeholders, each of whom might bring different, potentially conflicting, agendas (see discussion of Peace Nexus's Morocco trust fund, page 19). Similarly, initiatives applying to multiple countries may face added complications in navigating the regulatory and support provider contexts of multiple jurisdictions. ${ }^{155}$ Piloting the initiative with a smaller scope may help to address initial challenges before it is scaled up. ${ }^{156}$

Actors seeking to establish a financing initiative should pay attention to the context in which the initiative would operate, anticipating and avoiding political obstacles to the initiative's effective operation. If an initiative is perceived as a threat by powerful actors (such as public officials receiving illicit benefits from a company or bar associations resistant to making services cheaper if that would reduce revenues for their members), they may seek to shut down or block the initiative. ${ }^{157}$ Options to avoid, or minimize the impacts of, such challenges include: closely involving powerful actors from the early stages to encourage their buy-in; piloting the initiative in areas or sectors outside of such actors' sphere of influence or interest; and seeking legal advice to make sure an initiative is established in accordance with domestic laws, which could help avoid legal challenges by actors threatened by its existence.

\section{Political economy}

Introducing a financing initiative may create political economy implications that should be carefully addressed. Opportunistic actors, for example, may regard an initiative as a new source of money more generally-especially in low-income country contexts where communities, government, and other local actors are typically under-resourced. This can encourage undesirable outcomes, such as corruption, local elite capture, rent seeking, or an increased number of frivolous legal claims. A new source of potential funding may also have unintended effects on existing support providers. For example, it may elevate support providers who are savvy fundraisers over those who more effectively serve the interests of communities. ${ }^{158} \mathrm{~A}$ new initiative could also distort a support provider's priorities, causing it to alter how it supports specific communities or, more generally, to "follow the money," creating new support gaps for the less remunerative work it leaves behind.

A financing initiative can take various steps to address such concerns; for instance:

- Drawing on a network of existing, trusted support providers (usually local CSOs), particularly those that have already worked with the communities eligible for financing, can minimize rent seeking from unscrupulous actors. ${ }^{159}$

- Quality control measures may also be helpful, to increase the likelihood that support providers who are financed will faithfully serve the community's needs in line with the financing initiative's objectives. These can include conducting due diligence on support providers (including requiring references, proof of expertise or experience, and/or endorsement from professional bodies) and regular surveys and other low-cost monitoring strategies to gauge the satisfaction of the community or a CSO supporting the community with each support provider financed. A balance will need to be struck between the degree of scrutiny each potential support provider receives and the need to minimize the cost of doing so. ${ }^{160}$

- Investing in the development of future support providers through scholarships, training, and other relevant interventions can also help increase the number of appropriately qualified and locally-based support providers, although this may require significant amounts of money and time. 
- Strong governance arrangements (see below), including an arrangement for a third party to collect and allocate money, will help avoid misappropriation.

\section{Governance}

A financing initiative must be administered fairly and must guard against misappropriation of money. Steps must also be taken to avoid contributors having, or being perceived to have, undue influence over recipients, whether communities or support providers. ${ }^{161}$ These attributes can be facilitated by incorporating the following features:

- Mission and guiding principles. Having an overarching mission-for example, "to finance legal and technical support to empower communities to protect their human rights and advance their sustainable development in the context of investment"-can help orient an initiative and ground the development of spending criteria. A mission can be aided by guiding principles; for example: "funding should not be used to influence a community or support provider," "nobody should interfere with a community's relationship with its support provider," "the provision of funding should avoid the potential for division or conflict within a community," or "no one gets rich from the financing initiative." 162

\section{- Criteria for the management, allocation, and use of} money. Pre-designed criteria that guide the operational and implementation aspects of the initiative can help to achieve the initiative's objectives. Criteria can help manage and predict expenditures and reduce the risk of misappropriation. Such criteria can also mitigate risks that money might be used in unintended ways-such as for frivolous cases or non-priority legal strategies-that would disproportionately deplete the initiative and discourage funding sources from contributing initial or additional funding. Spending criteria can include:

- Acceptable types of support providers. Can communities use the money to procure support from CSOs, legal professionals, and/or non-legal experts?

- Processes for which support can be financed. Are any processes or strategies, such as litigation, not permitted?
- Any monetary limits. For example, the Time's Up Fund imposes monetary caps for different litigation stages, such as evidence gathering, pre-filing work and negotiation, trial litigation, and appeals (see Box 4, above). ${ }^{163}$

- A trusted, impartial administrator. The financing initiative should be administered by a trusted entity (potentially aided by an equally trusted advisory council $\left.{ }^{164}\right)$. The nature of this entity will depend on the source of the money, among other factors. For instance, if companies are the primary funding source, they may prefer to entrust independent entities with experience managing and disbursing money. Similarly, while a government that marshals revenue may be reluctant (and/or legally unable) to delegate authority to spend that revenue to a non-governmental entity, it may be willing to entrust an independent public entity such as a national human rights institution.

- Oversight bodies and processes. Additional checks on how the initiative operates can include appointing independent watchdogs ${ }^{165}$ or oversight boards ${ }^{166}$ and establishing grievance procedures.

- Community autonomy. To help mitigate power imbalances and encourage support providers to be responsive to community priorities, the choice of support provider, both before and during the provision of support, must reside with the community itself, even if the money that pays for it is managed by a trusted CSO working with the community. This will help the community to be empowered, and not controlled, by its support provider; it can also help minimize the risk of the support provider-client relationship being undermined by the fact that a third party is financing the support. ${ }^{167}$ Giving communities control over who supports them will also help catalyze community rights, such as the right to give or withhold free, prior and informed consent. ${ }^{168}$ Such community choices may be subject to reasonable restrictions, discussed above.

- Quality control measures (discussed above). 


\section{LINKING THE FINANCING INITIATIVE WITH COMMUNITIES AND SUPPORT PROVIDERS}

Actors establishing a financing initiative should reflect carefully on how to enable communities using available funding to procure the support they need. Issues to consider include:

- Can local CSOs act as a bridge between communities, funding, and support providers? Communities may not always seek support when needed and, when they do, might not be aware of an available financing initiative or of specific support providers that have the skills and experience needed. ${ }^{169}$ Awareness raising, training, and other educational efforts-both about investment processes more generally and about the financing initiative in particular-may help to address these challenges. ${ }^{170}$ In addition, local CSOs can play an important bridging role. CSOs can help identify when a community needs additional support, are more likely to know of any available financing initiative, and can assist the community in accessing, funding, and making good use of the support they need. ${ }^{171}$

- What if no relevant local CSO exists? Communities searching for legal support funding without the help of a local CSO may need to be connected with relevant support providers. In some cases, no relevant locallybased CSO may exist. In such a situation, a financing initiative should be prepared to support the community in a neutral but empowering manner to locate the support it needs. This may include, for example, working with the local community to develop a governance structure that could take the lead in identifying support providers through outreach to different organizations. Or it might include helping to identify a local CSO with some relevant skills and experience working with communities (even if not on issues relating to investments). A third strategy would be to maintain a network or register of relevant support providers. To build trust and enable the community to select support providers without feeling influenced by the financing initiative, it might be preferable for a trusted third party to maintain the network. For instance, a network of support providers could be maintained by a national human rights institution, as discussed in "Proposal: Financing legal services through company fees in Sierra Leone," above. Alternatively, an initiative may need to consider helping to establish new local organizations that can adequately support communities, ${ }^{172}$ although this can be an expensive and long-term endeavor.
- Who makes the payment to each support provider? Transferring money directly to communities on the understanding that they would then pay support providers could present some risks, including misappropriation or internal community disputes over how the money will be managed. Yet many CSOs may be subject to similar risks if they are not accustomed to managing large amounts of money. ${ }^{173}$ Further, communities need to choose which support providers are financed. Direct transfers to communities thus might be appropriate-or even preferable-in some circumstances. For instance, if a company offers direct funding and the community has a reliable plan to manage it, transferring money to the community may be more suitable than having the company pay the community's support provider directly. For other financing approaches, it may be preferable to have clear rules that place the choice of support provider squarely within the community's control (subject to the criteria discussed in "Governance," above), while having the financing initiative itself actually making payments to each support provider. 

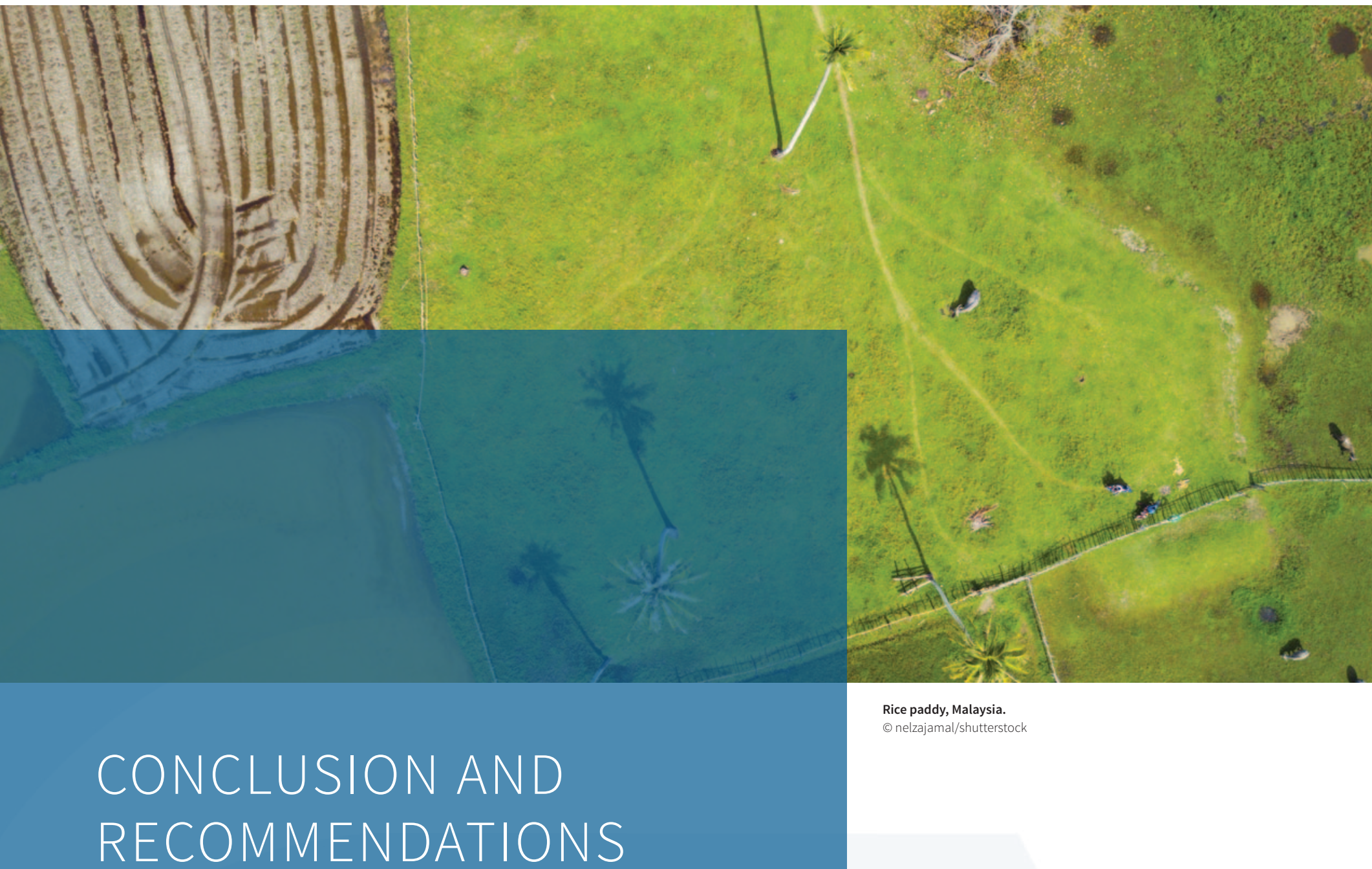

Rice paddy, Malaysia.

(c) nelzajamal/shutterstock

\section{CONCLUSION AND RECOMMENDATIONS}

Around the world, communities affected by land and resource investments have an urgent need for increased funding for the legal and technical support required to protect their rights and interests. New financing models exist, but require both catalytic and sustained efforts by a range of different actors. Each model also presents its own challenges, which must be carefully addressed. This report calls different stakeholders to action to use the tools available to them to advance opportunities to fill the financing gap. 
It remains to be seen whether a global initiative or a patchwork of different smaller-scale initiatives is the optimal way to meet the support needs of affected communities. In the meantime, different financing solutions for various scales and contexts should be tested. At the same time, the potential for a global initiative-financed by, for instance, significant bilateral and multilateral aid, philanthropic grants, and private sector contributions as part of a collaborative effort to advance SDG 16-should be explored.

Any new financing initiative should strive first and foremost to empower affected communities. Among other things, this means assessing current and potential power imbalances, and developing governance approaches that avoid the replication of imbalances within the initiative and that remedy imbalances outside of it. And while the incentives of potential funding sources should be factored into an initiative's design, the needs and priorities of the ultimate recipients of the supportcommunities-must fundamentally shape the initiative. Otherwise, any financing initiative that is developed risks becoming a pot of money that falls far short of its objectives, is under-used, or-worse still-causes internal fracturing, division, and fall out within specific communities or CSOs.

In line with the findings of this report, we offer the following recommendations:

Donors, including foundations and bilateral and multilateral aid organizations, already deploy grants to provide crucial funding for community support. This should continue. In addition, donors should:

- Leverage their extensive capital, experience, and access to different stakeholders to catalyze, pilot, and help establish new financing initiatives.

- Act as an impartial interlocutor to facilitate cooperation on the issue, including between actors who may not be accustomed to collaborating in highly politicized or contentious contexts.

- Focus, in particular, on the potential for basket funds to transform short-term donor funding and facilitation efforts into long-term, self-sustaining financing initiatives that significantly improve community access to legal and technical support.

- Continue to advance strategies for supporting the next generation of global-south based community support providers.
Host governments can play a range of productive roles to increase available funding for community legal and technical support. Specifically, governments:

- Can seek to establish financing initiatives, and marshal additional revenues to finance them. Any such initiatives should carefully incorporate the needs and perspectives of communities and support providers in line with this report.

- Should sensitize companies about the importance of adequately and appropriately financed community support. Where a basket fund or other relevant financing initiative exists, governments should encourage companies to contribute funding. Where it does not, governments could encourage companies to explore the potential for the establishment of a new, independently structured initiative.

- Should establish adequate legal frameworks to facilitate and adequately regulate potential private sector- or practitioner-focused solutions for financing legal support, including third party funding, contingency and uplift fees, fee recovery rules, and, potentially, legal insurance.

Communities and the CSOs that support them can use the solutions and considerations in this report to develop concrete funding-related requests, demands, advocacy campaigns, and negotiation strategies. For those communities or CSOs interested in promoting such opportunities, they should identify strategic moments-such as when laws or policies concerning land and investment are being drafted, or moments where international or national attention can be captured-to create pressure, and advance arguments and ideas, for establishing expansive and robustly-governed financing solutions.

Private sector actors should use their financial resources and spheres of influence to contribute to appropriately structured and governed basket funds and other financing initiatives.

- Agribusiness, forestry, and other natural resource companies should finance basket funds that apply beyond individual projects, and should commit to contributing funding regularly, on a long-term basis.

- Buyers of agricultural or forest commodities-such as companies from the food and beverage industry, among a range of others-should contribute funding to basket funds and encourage or require the companies they buy from to also do so. 
- DFIs and private financiers should share expertise to help with the establishment and operation of robustly governed, independent basket funds. They should also consider contributing funding to relevant basket fundsto help seed them, to cover their operational costs, or to be pooled with other money collected. Finally, DFIs and private financiers should encourage or require client companies to contribute funding to basket funds.

- MSIs and other bodies with company members should continue to innovate and, when relevant, work to make their own financing initiatives more accessible to communities and their support providers. Such bodies should also consider contributing funding to independently established basket funds and encouraging or requiring their member companies to do so.
Impact investors and impact investment funds should continue to explore the possibility of investing in community support, and ensure that any investments avoid onerous and unrealistic repayment obligations for communities.

Fee-charging lawyers should:

- Ensure any proposed third party funding agreements protect the lawyer-client relationship and preserve the community's ultimate ability to control decisions that will affect their rights and interests.

- Investigate the legality and feasibility of charging contingency or uplift fees for community clients, and ensure that the terms of such fees are fairly calibrated.

- Explore ways to reduce costs for community clients, including by unbundling legal tasks so that some tasks can be undertaken by community members or by less costly support providers.

- Consider accepting in-kind repayments or affordable, reduced user fees paid by community members themselves.

- For litigated matters, consider the feasibility of applying to the court for advance funding of the community's costs before the case proceeds and/or for fee shifting afterwards.

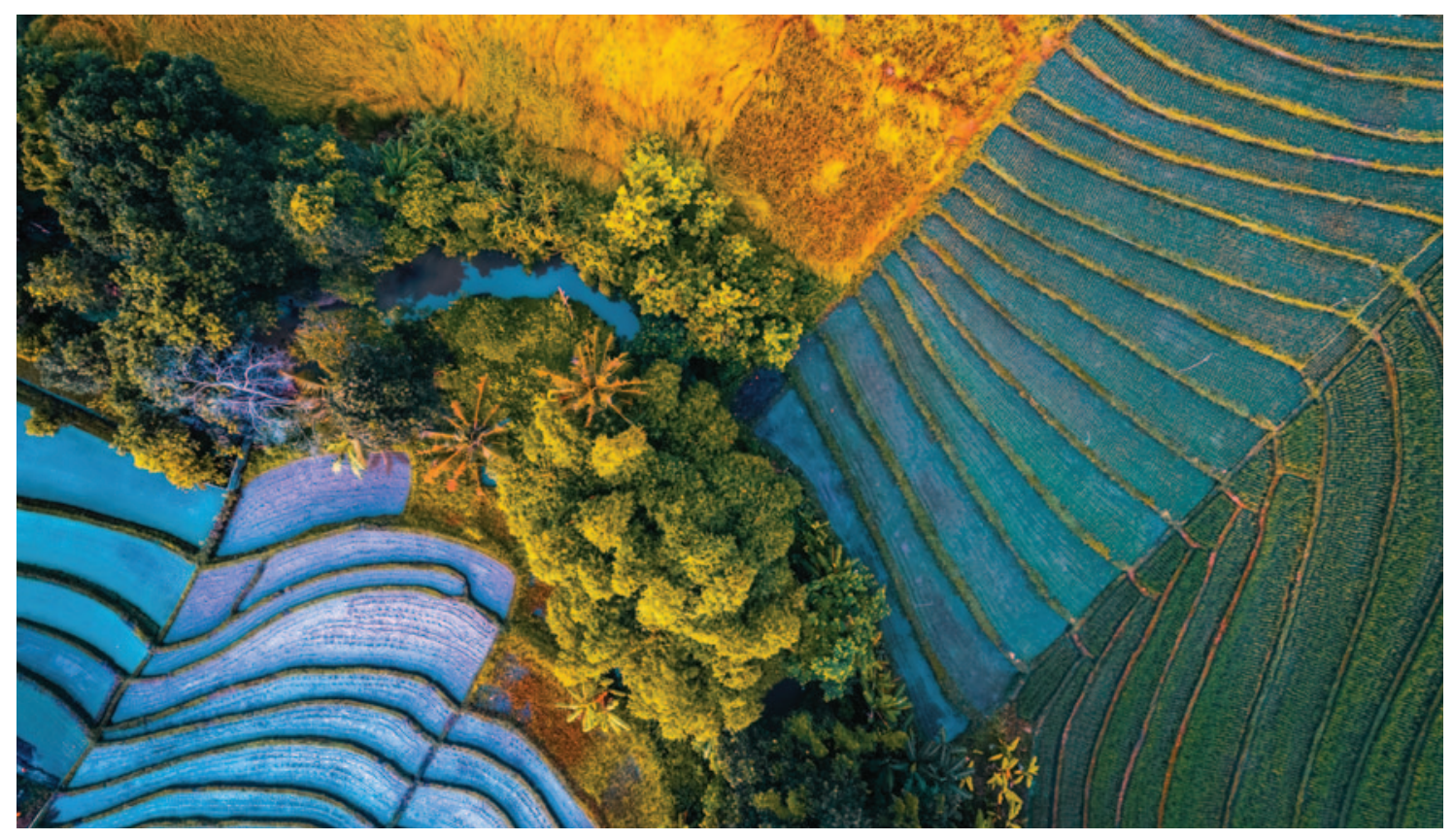




\section{ENDNOTES}

1. Bauer, J, "Stakeholder-Business Engagement Fund: Mapping Fund Components and Strategic Considerations” (Oct. 2014) (copy on file with the author), p. 1 (“.. funding to support the empowerment of communities to effectively exercise their rights, present their case, and engage with companies is generally lacking.")

2. Report of the Special Rapporteur on the situation of human rights and fundamental freedoms of indigenous people, (2009) U.N. Doc. A/HRC/12/34, para. 51 (noting that consultation procedures for Indigenous peoples are often "not effective" and that imbalances of power need to be addressed by, among other things, ensuring communities have the "financial, technical and other assistance they need" without such assistance being used "to leverage or influence indigenous positions in the consultations").

3. Inter-American Commission on Human Rights, "Indigenous and Tribal Peoples" rights over their ancestral lands and natural resources" (2009), para. 312.

4. Goodland, R, "Free, Prior and Informed Consent and the World Bank Group," Sustainable Development Law \& Policy Vol 4 Issue 2, (2004) (noting, in a discussion of meaningful participation of communities affected by World Bank-funded projects, that "Balanced negotiation demands education of stakeholders (governments, proponents, affected communities) on their rights and responsibilities. Such negotiations between asymmetrical parties usually need advocates, facilitators, and technical assistance.")

5. See, e.g., Conteh, S, "How not to conduct Large-scale Agricultural Investments: Lessons from the Malen/Socfin Land dispute in Sierra Leone," http://standardtimespress.org/?p=8383 ("the 2011,2012 and 2013 lease/sub-lease agreements and the processes leading up to them were fundamentally flawed. [.. ] Any insistence that due process was followed in the [negotiation of the] previous lease arrangement is disingenuous. The severe power imbalance between the parties and the lack of independent legal support to the communities ensured that any outcome was bound to be skewed.")

6. See, e.g., Lakhani, N, "Honduras and the dirty war fuelled by the west's drive for clean energy," The Guardian (2014), https://bit.ly/2EtpqjR (describing targeted killings in Honduras of more than 100 protestors claiming that oil palm concessions were "fraudulently and coercively transferred to agribusinesses" in a dispute that has lasted two decades).

7. Locke, A, Munden, L, Feyertag, J and Bowie, B, Assessing the Costs of Tenure Risks to Agribusiness (Feb. 2019), pp. 6, 7, 14 https://bit.ly/2H35Rlh.

8. Locke, A, et al, Assessing the Costs of Tenure Risks to Agribusiness (Feb. 2019), p. 11, https://bit.ly/2H35Rlh

9. See, e.g., UNODC, "Global Study on Legal Aid Global Report" (2016) pp. 2-3, https://bit.ly/2C2jv4S; International Forum on Legal Aid, Legal Aid and the Universal Value of Human Rights, 2014 Conference Proceedings, p. 248 http://bit.ly/2Cd15i7. See also World Justice Project, "Global Insights on Access to Justice," (2018), https://bit.ly/2C4OblU and the national justice needs surveys of the Hague Institute for Innovation of Law (HiiL) for Bangladesh, Fiji, Jordan, Kenya, Mali, Morocco, Nigeria, Tunisia, the Ukraine, and the United Arab Emirates: https://www.hiil.org/projects/?_sf_s=legal\%20needs.

10. Among the multiple challenges in quantifying the need is the lack of transparency that continues to obscure many land investments. Yet another significant challenge is that communities themselves often do not realize that they would benefit from legal and technical support until it is too late for anything but resolving grievances or seeking redress for harms. Recent research by Namati also shows that this lack of awareness often exists even for communities that have already received general legal empowerment support around land rights and community land protection: Knight, R, "Community Capacity to Respond to External Threats to their Land Claims," Namati (forthcoming Apr. 2019).

11. Colchester, M, Chao, S, Anderson, P, and Jonas, H, "Free, prior and informed consent guide for RSPO members" (2015), p. 90, https://bit.ly/2GXIOJg “Field reviews carried out to date show that very few communities have had the key RSPO requirements, that companies must respect their land rights and assure FPIC, explained to them prior to the land acquisition process. This makes it possible for companies to persuade communities to accede to sub-optimal land acquisition processes unaware that they entitled to more. This points to the need for a much wider system for ensuring that communities are independently informed of their rights and entitlements, and have access to legal counsel and technical advice. How may this be assured? [...] The RSPO is currently undertaking a review to ascertain to what extent so-called 'intermediary organisations' such as IMOs, legal support organisations and other elements of civil society can help fulfil such needs."). See also p. 116 (noting that "the lack of access to information and company grievance mechanisms contributes to the ongoing fact that without NGO engagement, most communities are unable to activate such mechanisms or seek redress where rights have been violated.")
12. Interview with civil society representative, Jan. 14,2019.

13. Interview with civil society representative, July 7, 2017 ("experts often can't afford to work pro bono, sometimes low bono, but they're not with big law firms that subsidize. If they work with a company, the company won't let them work on it or do it pro bono."); Interview with impact investment fund representative, Nov. 20, 2018 ("[one legal expert] thinks there are 12 lawyers in world who have 25 years of mining experience and have not worked for mining companies. They get a lot of requests for pro bono assistance but can't even answer every request let alone say yes to everything."); Comment from peer reviewer, March 3, 2019.

14. Bauer, J, "Stakeholder-Business Engagement Fund: Mapping Fund Components and Strategic Considerations" (Oct. 2014), p. 1 ("funding to support the empowerment of communities to effectively exercise their rights, present their case, and engage with companies is generally lacking").

15. Boudreaux, K, Vhugen, D and Walter, N, “Community Land Conflicts: How Local Land Disputes Affect Private Sector Investments And Development Projects" (2017), pp. 32 36 ("the investment or donor project implementer might also provide technical or legal assistance to the parties to the conflict. This can take many forms such as providing financial assistance that allows parties to retain a lawyer or other advisor. Another alternative is to help the parties gain access to NGOs that may provide advice and support to local community members seeking to enforce their rights;" "If land disputes are identified, investors and implementers can [...] (2) provide financial and technical assistance to the parties to the conflicts"); Nielsen, R, "Sustaining Legal Empowerment In Initiatives To Support Local Land Rights," (2012), http://pubs.iied.org/pdfs/G03513.pdf ("Recommendations for donors and project sponsors: [...] Fund national organisations, coalitions, or networks committed to legal empowerment; Consider use of basket funds and other collective funding systems").

16. Conteh, S, "How Not To Conduct Large-Scale Agricultural Investments: Lessons From The Malen/Socfin Land Dispute In Sierra Leone" ("The severe power imbalance between the parties and the lack of independent legal support to the communities ensured that any outcome was bound to be skewed"); Jochnick, C, "Can Corporate Campaigners Tap Corporate Largesse? Unlocking Millions For Human Rights Advocates," Open Democracy, (Dec. 30, 2013), https://bit.ly/2SArVLh ("Too much potential funding sits out of reach of these groups"); Maru, V, "The World Bank shouldn't hide when it funds projects that harm communities," https://wapo.st/2Vya8RE ("For communities to stand a chance alongside huge corporations and major development institutions, they should have access to adequate legal resources of their own"); Knight, R, "Community Capacity to Respond to External Threats to their Land Claims," Namati (forthcoming April 2019).

17. Interview with civil society representative, Jan. 3, 2019.

18. Cotula, L, Berger, T, Knight, R, Mclnerney, T, Vidar, M, and Deupmann, P, "Responsible Governance Of Tenure And The Law: A Guide For Lawyers And Other Legal Service Providers, Food And Agriculture Organization Of The United Nations," (2016), pp. 82-83, http://www.fao.org/3/a-i5449e.pdf (noting that "[b]usinesses taking a longterm perspective may wish to help communities obtain legal representation, knowing that a better-negotiated deal is ultimately more advantageous for both parties" and that this "could include financial support," but that company funding "also raises questions about conflicts of interest," before noting the needs for "technical solutions [that can help mitigate risks" and "for this type of lega assistance to be eligible for legal aid.")

19. Interlaken Group Meeting Summary (2018), https://bit.ly/2HcDK3d ("Alternative Land Use Agreements. In addition, participants highlighted the following best practices: [...] Ensure a fair negotiation process by hiring a community liaison officer and ensuring communities receive independent advice (e.g., finance their legal assistance if needed)."); Colchester, M, Chao, S, Anderson, P, and Jonas, H, "Free, prior and informed consent guide for RSPO members," (2015), p. 90, https://bit.ly/2GXIOJg (describing "the need for a much wider system for ensuring that communities are independently informed of their rights and entitlements, and have access to legal counsel and technical advice.")

20. United Nations Sustainable Development Solutions Network Thematic Network on the Good Governance of Extractive and Land Resources, Columbia Center on Sustainable Investment, the International Council on Mining and Metals, GIZ and the World Bank, "Renewable Energy and the Sustainable Development Goals Exploring Land Links with Extractives, Agriculture and Land Use," p. 8, https://bit.ly/2EKxiis ("Action items: Research options for creating "black box" funding to provide communities with the legal support they may need, including for negotiations or in cases of disputes associated with land-based investments.")

21. See the discussion of Peace Nexus Morocco and the Samdhana Trust Fund under "2. Basket funds," below.

22. For more information about how communities can prepare themselves before investors arrive, see Columbia Center on Sustainable Investment (CCSI) and Namati, "Community-Investor Negotiation Guide 1: Preparing in Advance for Potential Investors," (2018), pp. 9-29, https://bit.ly/2PDLD2q. 
23. See CCSI and Namati, "Community-Investor Negotiation Guide 1: Preparing in Advance for Potential Investors," (2018), pp. 30-49.

24. See CCSI and Namati, "Community-Investor Negotiation Guide 2: Negotiating Contracts with Investors," (2018), https://bit.ly/2wUaRTp.

25. This option is discussed in the context of financing legal aid more generally in LDP, "Developing a Portfolio of Financially Sustainable, Scalable Basic Legal Service Models: Briefing Paper" International Development Research Centre, the Legal Education Foundation and Open Society Foundations (2016), p. 11 https://bit.ly/2UsbQ76.

26. LDP, "Developing A Portfolio Of Financially Sustainable Scalable Basic Legal Service Models," Vol. 1, International Development Research Centre, the Legal Education Foundation and Open Society Foundations (2015), p. 33, https://bit.ly/2tLNSI7.

27. UNODC, "Global Study on Legal Aid Global Report," (2016), pp. 2 and 3, https://bit.ly/2C2jv4S.

28. See, e.g., Mertenskötter, P and Stewart, R. B., "Remote Control: Treaty Requirements for Regulatory Procedures," IILJ Working Paper 2018/2 (MegaReg Series), pp. 8-10, https://bit.ly/2TnOr9L (explaining McNollgast's principle-agent alternative control strategy, noting that "political principals [here, host governments] can establish administrative procedures [or here, empower communities to engage with accountability mechanisms] that can be mobilized by private actors [here, communities] to pursue their own interests in ways that are aligned with those of the principals [here, by encouraging investor legal compliance].")

29. United Nations Security Council, "Thirty-second progress report of the SecretaryGeneral on the United Nations Mission in Liberia," (2016), U.N. Doc. S/2016/706, paras. 69 (noting that "concession-related disputes continue to pose risks to stability, in particular when promises made to communities with regard to economic and social development opportunities are not honoured, the environment is degraded and workers' salaries are not paid") and 18 (noting that "concession-related labour and land disputes, some of which turned violent, were the primary causes of tensions."). See also LDP, "Developing A Portfolio Of Financially Sustainable Scalable Basic Legal Service Models," Vol. 1, (2015), p. 72 (noting that in China, "[l]egal aid is considered critical to promoting social harmony; if the state responds to basic grievances, then the population is less likely to revolt").

30. LDP, "Developing A Portfolio Of Financially Sustainable Scalable Basic Legal Service Models," Vol. 1, (2015), p. 70 (noting that "in fragile and conflict-affected states, where basic service delivery has ceased, and the state needs to quickly build trust by reasserting its role and its value to its citizens $[; \ldots$ one $]$ method that states have to prove their legitimacy is through providing services").

31. Aboriginal Consultation Levy Act, (2013), Chapter A-1.2, https://bit.ly/2EKMYCi.

32. The Canadian Press, "Alberta Government Moves To Repeal Contentious Aboriginal Consultation Bill," (2016), Edmonton Sun, https://bit.ly/2XyXl3c.

33. Sweetgrass, S. N., "Legal challenge Pending on Aboriginal Consultation Levy Act," Aboriginal Multi-Media Society (AMMSA), (2013), https://bit.ly/2VFljbB.

34. Discussed in Bauer, J, "Stakeholder-Business Engagement Fund: Mapping Fund Components and Strategic Considerations" (Oct. 2014), p. 6. See also Constitution of Telecommunications Industry Ombudsman Limited ACN 057634787 [Incorporating amendments] (2018), ss 7 and 9, https://bit.ly/2SBSKK4.

35. Comment from peer reviewer, March 3, 2019.

36. Sierra Leone, "Draft Guidelines for Sustainable Agricultural and Bioenergy Investment," (2013), p. 11 http://www.fao.org/3/a-bp863e.pdf.

37. Sierra Leone, "Draft Guidelines for Sustainable Agricultural and Bioenergy Investment," (2013), pp. 11-14, 16

38. The policy also envisages the legal representative would be present during consultations before contract negotiations: Sierra Leone, "Draft Guidelines for Sustainable Agricultural and Bioenergy Investment,” (2013), p. 12.

39. UNODC, "Global Study on Legal Aid Global Report," p. 31.

40. Government of Sierra Leone, "Final National Land Policy of Sierra Leone," Version 6, Ministry Of Lands, Country Planning and The Environment (2015), pp. 66-7 http://extwprlegs1.fao.org/docs/pdf/sie155203.pdf

41. Mortensen, R, "Interest on Lawyers' Trust Accounts," 27(2) Sydney Law Review 289 (2005)

42. Legal Practitioners Act (Act 15 of 1995) (Namibia), s. 71; Attorneys Act (Act No. 53), 1979 (South Africa), ss. 26 and 46 (and formerly Legal Practitioners' Fidelity Fund Act, 1941); Legal Practitioners Act (Chapter 27:07), 1981 (Zimbabwe), s 50; Law Society Compensation Fund Act (Chapter 222 of 1974) (Zimbabwe).
43. Legal Profession (Amendment) Act 2018 (Singapore), s. 70J, https://bit.ly/2TfljRE.

44. Legal Profession Act, Cap 370A (1978), s. 49 (Barbados); International Forum on Legal Aid, "Legal Aid and the Universal Value of Human Rights," 2014 Conference Proceedings, p. 248, https://bit.ly/2Cd15i7.

45. Legal Practitioners Act (Act 15 of 1995) (Namibia), s. 71; Attorneys Act (Act No. 53), 1979 (South Africa), s. 26

46. Legal Practitioners Act (Act 15 of 1995) (Namibia), s. 71; Attorneys Act (Act No. 53) 1979 (South Africa), s. 46

47. Maisel, P, "Expanding and Sustaining Clinical Legal Education in Developing Countries: What We Can Learn from South Africa," 30 Fordham International Law Journal 374 (2007), p. 388

48. See World Bank, "Mining Foundations, Trusts and Funds: A Sourcebook," (June 2010), p. 28 https://bit.ly/2TolaL0 (discussing these two main programmatic approaches: granting making and operational or implementation).

49. World Bank, "Mining Foundations, Trusts and Funds: A Sourcebook," (June 2010), p. 51 (comparing grant making organizations which had 6 to 20 staff with operational / in-house funds which had 60 to 100 staff).

50. CCSI, DIHR, and Sciences Po Law School Clinic, "A Collaborative Approach to Human Rights Impact Assessments," (2016), p. 63

51. See Locke, A, Munden, L, Feyertag, J and Bowie, B, Assessing the Costs of Tenure Risks to Agribusiness (Feb. 2019)

52. Interview with university clinic representative, June 27, 2017; Interview with civi society representative, June 30, 2017; Interview with DFI representative, Dec. 11 2018; Interview with multi-stakeholder body representative, Oct. 4, 2018 "Companies want contracts with communities. They want confidence that the agreement will stand up for 25 years, so there is a huge incentive for companies to get that final agreement correct. And they want to make sure that community is regarded as appropriately supported so the contract can't be challenged.")

53. Interview with civil society representative, July 10, 2017; Interview with university clinic representative, June 27, 2017; Interview with DFI independent accountability mechanism representative, Jan. 23, 2019.

54. Interview with civil society representatives, Jan. 29, 2019. One CSO refused to receive funding to support communities affected by a forestry project because the funding would be provided by the proponent company of that forestry project: Interview with DFI representative, Dec. 11, 2018.

55. Interview with multi-stakeholder body representative, Dec. 5, 2018.

56. Interview with multi-stakeholder body representative, Oct. 4, 2018; Interview with civil society representative, June 30, 2017; Interview with multi-stakeholder body representative, Dec. 5, 2018

57. Interview with MSI representative, Jan 30, 2019

58. Interview with academic representative, July 12,2017.

59. Interview with DFI representative, Dec. 11, 2018.

60. IFC Performance Standards on Environmental and Social Sustainability (2012), Standard 7, paras. 10-17. See, especially, para 11 (noting in certain circumstances "the [company] client will engage external experts to assist in the identification of the project risks and impacts.")

61. See, e.g., Bonsucro Production Standard v. 4.1 (2015), Principles 1.2, 5.7, 5.8; Forest Stewardship Council Principles and Criteria for Forest Stewardship v. 4 (2002), Principles 2.2, 3.1 and 3.4; Roundtable on Responsible Soy Standard for Responsible Soy Production Version 2.0 (2013), Principle 3.2.2: Roundtable on Sustainable Palm Oil Principles and Criteria for Sustainable Palm Oil Production (2018), Principles 4.4, 4.5, and 4.7 .

62. Interview with MSI representative, Jan. 30,2019.

63. Interview with civil society representative, June 30, 2017; Interview with foundation representative, March 1, 2019

64. Interview with civil society representative, July 11,2017 ; Interview with university clinic representative, June 27,2017 . See also discussion of a similar phased approach to funding in the context of collaborative human rights impact assessments, CCSI, DIHR, and Sciences Po Law School Clinic, "A Collaborative Approach to Human Rights Impact Assessments (2017), pp. 61-62.

65. Interview with impact investment fund representative, July 6, 2017. 
66. Interview with civil society representative, July 24, 2017: World Bank, "Mining Foundations, Trusts and Funds: A Sourcebook" (June 2010), p. 53 (noting that "while company foundations are often assumed to operate at a local level, focussing on their direct area of influence, five of the nine company foundations reviewed here operated at either regional or national levels.").

67. World Bank, "Mining Foundations, Trusts and Funds: A Sourcebook" (June 2010), pp. 62, 66 ("Transparency is considered even more important when companies contribute to government supported or mandated FTFs to ensure that funds are being used for their intended purposes and to minimise any speculation of bribery or corrupt practices between the two parties."); Interview with impact investment fund representative, July 6, 2017.

68. Interview with company representative, Feb. 20, 2019.

69. Interview with multi-stakeholder body representative, Oct. 4, 2018; Interview with multi-stakeholder body representative, Dec. 5, 2018; Arljung, M and Hansson, L, "Bridge Over Troubled Waters: How Can We Bury the Hatchet Between Industry and Civil Society?", Siani (2018) https://bit.ly/2FmCHsP; Kumacaya website funding offers for "Workers Welfare - East Kalimantan, Indonesia" and "FPIC - Grand Kru \& Maryland, Liberia," www.kumacaya.org.

70. RSPO, "Dispute Settlement Facility," https://www.rspo.org/members/disputesettlement-facility; Interview with MSI representative, Dec. 11, 2018.

71. RSPO, Membership Application requirements, https://rspo.org/members/apply

72. Interview with MSI representative, Dec. 11, 2018; Interview with civil society representative, Jan. 3, 2019.

73. Interview with civil society representative, Jan. 3, 2019

74. PeaceNexus Foundation, "Company-Community Trust Fund - DRAFT Concept Note for Pilot Testing” (2015), p. 1

75. Institute for Conflict Transformation and Peacebuilding, "Company-Community Trust Fund: Interview with Santiago Porto" (2015), p. 5.

76. Interview with civil society representative, July 11, 2017

77. This text box draws from email communications with Patrick Anderson.

78. UNDP, "Impact investment," (2016); Turley, L and Uzsoki, D, "Financing Rura Infrastructure: Priorities and pathways for ending hunger," International Institute for Sustainable Development (IISD) (2018), p. 6, https://bit.ly/2FBjszs.

79. Duflo, E, "Microcrédit, Miracle Ou Désastre ?," Le Monde (2010) https://lemde.fr/2GV1oC9.

80. LDP, "Developing a Portfolio of Financially Sustainable, Scalable Basic Legal Service Models: Briefing Paper" (2016), p. 11.

81. Notterman, B, "Leveraging Civil Legal Services: Using Economic Research and Socia Impact Bonds to Close the Justice Gap," The Harbinger: N.Y.U. Review of Law \& Social Change (Vol. 40), https://bit.ly/2EJhpsi.

82. UNDP, Social and Development Impact Bonds (2016), https://bit.ly/2H360WX.

83. UNDP, Social and Development Impact Bonds (2016).

84. UNDP, Social and Development Impact Bonds (2016)

85. Notterman, B, "Leveraging Civil Legal Services: Using Economic Research and Socia Impact Bonds to Close the Justice Gap," The Harbinger: N.Y.U. Review of Law \& Social Change (Vol. 40), ("by proving that civil legal services inure to the benefit of the entire public, not just those directly served, economic studies could broaden the political appeal of civil legal services.")

86. Root Capital, an impact investment fund, provides an example of how impact investors use data to develop a risk profile for impact and return. For its portfolio of impact investments in local agriculture projects, such as financing organic farmers cooperatives, Root Capital quantifies each investment's expected impact according to factors such as poverty levels, expected poverty eradication, environmental vulnerability, and number of individuals reached. The expected impact is then plotted against each investment's expected financial return to determine which investments would achieve an acceptable combination of impact and return. Root Capital, "Root Capital's Expected Impact Rating," (2017), p. 2; Bolis, M, West, C, Sahan, E, Nash, R and Irani, I, "Impact investing: Who are we serving?" Oxfam and Sumerian Partners, (2017), p. 13 https://bit.ly/2qsEMg3.

87. Interview with impact investment fund representative, Nov. 20, 2018

88. Comment from peer reviewer, March 5, 2019.

89. Interview with impact investment fund representative, July 6, 2017.
90. Comment from peer reviewer, March 6, 2019.

91. Levitt, D. A, Investing In The Future: Mission-Related And Program-Related Investments For Private Foundations, The Practical Tax Lawyer (Spring, 2011), pp. 33-34.

92. Foxworth, R, "Wealth Inequality and The Fallacies of Impact Investing" Medium (2018), https://bit.ly/2GOMr09 ("If we're truly motivated to deconstruct the wealth inequalities that have ravaged and extracted wealth from rural, indigenous, and majority people of color communities, then we must rid ourselves of the power dynamics, biases, and culture that got us here in the first place.")

93. Interview with impact investment fund representative, July 6, 2017; Bauer, J, "Stakeholder-Business Engagement Fund: Mapping Fund Components and Strategic Considerations" (Oct. 2014), p. 5.

94. Interview with impact investment fund representative, July 6, 2017.

95. Interview with impact investment fund representative, Nov. 20, 2018

96. Association of Litigation Funders, "Litigation Finance," https://bit.ly/2gn6p58.

97. Interview with litigation lawyer, Feb. 21, 2019.

98. Pitkowitz, N (ed), Handbook on Third-Party Funding in International Arbitration (2018), p. 99.

99. Interview with litigation lawyer, Feb. 21, 2019.

100. Woodsford Litigation Funding, "Is your case right for litigation funding?," https://bit.ly/2IQ9hun; Harbour Litigation Funding, "Our criteria," https://bit.ly/2TlyFw7.

101. Relatedly, some community litigation may desirably be brought as a class action, yet many jurisdictions are yet to have clear laws regarding whether class actions may permissibly be brought. See, e.g., Menges, W, "Hai//om sue for rights over Etosha," The Namibian, (Oct. 19, 2015) https://bit.ly/2C36g43.

102. See, e.g., Dugal v Manulife Financial Corporation, 2011 ONSC 1785 (February 8, 2011) (approving a funding agreement after considering factors including that the claimants retained control of the litigation remained in the hands of the representative plaintiffs, allowing for the funder to receive appropriate information about the case's progress, and that the court would supervise the arrangement), discussed in MacDonald, $\mathrm{H}$, "Third Party Litigation Funding: Plaintiff Identity and Other Vexing Issues," pp. 8-9 (2011) https://bit.ly/2XOxaWw.

103. Other appropriate norms include: ensuring the funder has adequate access to capital to fund the litigation; setting out the limited circumstances in which a funder may be permitted to withdraw from a case; and requiring formal undertakings that the funder will not cause the claimant's lawyer to breach their professional obligations or otherwise seek to influence the lawyer to cede control of the case: Association of Litigation Funders, Code of Conduct (2018) https://bit.ly/2ELEdaX.

104. Barrett, P, "The Fall of the House of Boggs," (Sept. 15, 2014), https://politi.co/2SIbUOq; Gayarthri, A, "Gibraltar Court Awards Chevron \$28 Million in Damages," Reuters, (Dec. 16, 2015) https://reut.rs/2EzCjJo; PanAm Post Staff, "Financial Backer in Chevron Lawsuit Throws in the Towel," (Feb. 17, 2015), https://bit.ly/2SCzMCZ

105. Topsfield, J, "Indonesian Seaweed Farmers Launch Class Action over Montara Oil Spill,” (Aug. 2, 2016) The Sydney Morning Herald, https://bit.ly/2GZ2o8h; Maurice Blackburn Lawyers, "Oil Spill now a \$200m+ Class Action for Seaweed Farmers," (Aug. 3, 2016) https://bit.ly/2XJOMD0.

106. Definition adapted from Churchill, C, McCord, M, "Current trends in microinsurance," in Churchill, C and Matul, M (eds), "Protecting the Poor: A Microinsurance Compendium," Vol II (2012), p. 8, https://bit.ly/2NDpu4P; Patel, S, "Insurance and Poverty Alleviation" (2002), pp. 21-2, https://bit.ly/2Hdz6BY.

107. Patel, S, Insurance and Poverty Alleviation (2002), p. 22.

108. Patel, S, Insurance and Poverty Alleviation (2002), p. 17; Eighty20 Consulting, Legal Expenses Insurance (2014), p. 17, https://bit.ly/2Vxy33R.

109. Patel, S, Insurance and Poverty Alleviation (2002), pp. 17-18.

110. Eighty20 Consulting, Legal Expenses Insurance (2014), p. 18.

111. Legal Wise, https://www.legalwise.co.za/

112. Eighty20 Consulting, "Legal Expenses Insurance," (2014), p. 21, https://bit.ly/2Vxy33R

113. Interview with impact investment fund representative, July 6, 2017 (noting that Native American communities have successfully obtained lump sums of funds as a condition to even beginning discussions and negotiations). 
114. Memorandum of Understanding between Northern Land Council and Rio Tinto Pty Ltd (2001), Art. 11.11, https://bit.ly/2GZ09BQ ("The Exploration Company shall [... meet the reasonable costs incurred by the Local Aboriginal Groups in connection with the negotiations for and in the preparation of a Mining Agreement, including the costs of consulting the relevant Local Aboriginal Groups and of any consultants and advisers [...]"); Collaboration Agreement between Northern Village of Pinehouse \& Kineepik Metis Local Inc and Cameco Corporation \&AREVA Resources Canada Inc (2012), Schedule G, p. 6, https://bit.ly/2C1U1Vs ("Cameco and AREVA provided the funding necessary to ensure that the Village and Kineepik were represented by independent legal counsel throughout the CA negotiation process"); Boakye, B, Cascadden, M, Kuschminder, J, Szoke-Burke, S and Werker, E, "Implementing the Ahafo benefit agreements: Seeking meaningful community participation at Newmont's Ahafo Gold Mine in Ghana" CIRDI, (2018), p. 33, https://bit.ly/2EwUajV.

115. See description of the Eagle Mine Community Environmental Monitoring Project, page 27. See also Boakye, B, et al, "Implementing the Ahafo benefit agreements: Seeking meaningful community participation at Newmont's Ahafo Gold Mine in Ghana" CIRDI (2018), p. 40 (describing a participatory monitoring initiative. The company is bound to provide training to participating community members; it could meet any costs of monitoring as well).

116. Direct company funding could more systematically help to address community support needs if consistently required by DFIs, MSIs, host governments, or other actors with leverage over companies. However, such actors could also potentially require contributions to basket funds, avoiding the inherent risks of direct company funding.

117. Interview with civil society representative, January 3, 2019 (noting an example when a local CSO accepted company funding to support a community through an MSIrelated grievance mechanism; Bauer, J, "Stakeholder-Business Engagement Fund: Mapping Fund Components and Strategic Considerations" (Oct. 2014), pp. 16 and 17 (noting the view of Brian Joseph, Senior Director of Asia and Global Programs at the National Endowment for Democracy, that "local civil society groups are much less wary about where the money comes from than are international NGOs"); Interview with DFI representative, Dec. 11, 2018 (Noting an example where a CSO refused to receive funding to support communities affected by a forestry project because the funding would be provided by the proponent company of that forestry project).

118. "Participation Agreement: Indigenous Land Use Agreement between Traditional Owners, Kimberley Land Council Aboriginal Corporation, Argyle Diamonds Limited and Argyle Diamond Mines Pty Limited" (2005), Art. 7 (pp. 57-58), https://bit.ly/2C3EODb.

119. For a more detailed summary of the CEMP, see CCSI, DIHR, and Sciences Po Law School Clinic, "A Collaborative Approach to Human Rights Impact Assessments" (2017), pp. 45-6.

120. Various crowd funding platforms exist for fundraising for legal fees, including CrowdJustice, https://www.crowdjustice.com/how-it-works/, Funded Justice, https://www.fundedjustice.com/, and Fundrazr's legal section: https://fundrazr.com/find?category=Legal. Other successful campaigns use platforms that are not exclusively focused on fundraising for support, such as the Time's Up Fund's use of GoFundMe: https://www.gofundme.com/.

121. See, e.g., Rojc, P, "Crowdfunding: Who Donates, And Why?" (2016), https://bit.ly/2Tc6OiE; Ron, J, Kaire, J, and Crow, D, "Ordinary People Will Pay For Rights. We Asked Them, Open Global Rights” (2017), https://bit.ly/2UiBBqx.

122. For instance, Village X's online fundraising platform promises data, including 13 development indicators, to demonstrate recipient organizations' impact: https://www.villagex.org/model.php

123. Orozco, D, "The Use Of Legal Crowdsourcing ("Lawsourcing") To Achieve Legal, Regulatory, And Policy Objectives," American Business Law Journal, Vol. 53, No. 1 (2016), p. 22 (citing the example of the social movement 15-M's crowd funding of $€ 19,000$ within 24 hours to bring a lawsuit against the former chairman of a Spanish Bank that had collapsed and received a bailout).

124. Song Mao \& Others v. Tate \& Lyle Industries Limited and T\& L Sugars Limited, Claim No. 2013 Folio 451

125. Kolisetty, A, "Examining the Effectiveness of Legal Empowerment as a Pathway out of Poverty: A Case Study of BRAC," World Bank (2014), p. 38, https://bit.ly/2EuAdKA; BRAC website http://www.brac.net/enterprises; LDP, "Developing A Portfolio Of Financially Sustainable, Scalable, Basic Legal Service Model,”Annexes, Vol. 2 (2015), pp. 52-55. Another example, revealed by the research of Lotta Teale in Teale, L, "Innovative Financing for Legal Empowerment: Options to Explore" (forthcoming; copy on file with the author), is the Orange Farm Human Rights Advice Centre in South Africa, which is partly funded by revenue received from recycling: https://bit.ly/2tMgMb5
126. Community Legal Education Center, http://www.clec.org.kh/services.php.

127. Kolisetty, A, "Examining the Effectiveness of Legal Empowerment as a Pathway out of Poverty: A Case Study of BRAC," World Bank (2014), p. 38, citing Neilsen, R, "Sustaining Legal Empowerment in Initiatives to Support Local Land Rights," International Institute for Environment and Development (2012), pp. 17-18 http://pubs.iied.org/pdfs/G03513.pdf.

128. Interview with civil society representative, Oct. 17, 2018; Interview with multi-stakeholde body representative, Dec. 5, 2018 (recalling a community in Indonesia that hired and paid for a lawyer themselves to challenge a government eviction notification).

129. Barendrecht, M, "Models for Sustainable Legal Aid: Experiences from NGO's in Five Lower Income Countries," TISCO Working Paper Series on Civil Law and Conflict Resolution Systems No. 002/2011 April 20, 2011, p. 12 (describing Deme So in Mali, which charges a small fee to obtain documents: "Instead of the official 3000 francs, the paralegal charges his clients 5000 francs. This still costs the clients far less than when they would have to arrange it themselves and at the same time provides for a fee for the paralegal's services," which might cost as much as 20,000 francs). See also LDP, "Developing A Portfolio Of Financially Sustainable, Scalable Basic Legal Service Models," (2015), Vol. 1, p. 20 (describing Microjustice4All: "Services are typically provided by paralegals and law students under the supervision of experienced lawyers in return for affordable fees which provide an element of cost recovery.").

130. Barendrecht, M, “Models for Sustainable Legal Aid: Experiences from NGO's in Five Lower Income Countries, TISCO Working Paper Series on Civil Law and Conflict Resolution Systems," No. 002/2011 (Apr. 20, 2011), p. 12.

131. Interview with civil society representative, Dec. 11, 2018; Barendrecht, M, "Models for Sustainable Legal Aid: Experiences from NGO's in Five Lower Income Countries,' TISCO Working Paper Series on Civil Law and Conflict Resolution Systems, No. 002/2011, (Apr. 20, 2011), p. 12; LDP, "Developing A Portfolio Of Financially Sustainable, Scalable Basic Legal Service Models,” (2015), Vol 1, p. 68.

132. In other contexts, some lawyers have even bargained to provide their services to newly-formed corporations in return for equity in the company: Dzienkowski, J and Peroni, R Texas Law Review, Austin Vol. 81, Iss. 2, (Dec. 2002): 405-549. While this is theoretically possible when a community seeks to form a company and enter into a joint venture with a company, there is a risk that such an arrangement would involve the community allocating away significant amounts of future revenue and should thus be approached with caution.

133. See, e.g., Victorian Law Reform Commission, "Access To Justice: Litigation Funding And Group Proceedings" (2018), para. 3.40, https://bit.ly/2SFzdIP ("The prohibition on lawyers being able to charge contingency fees arises from the need to avoid perverse incentives. Lawyers have fundamental duties, first to the court and the administration of justice, and, secondly, to their clients. Their ethical and professional obligations pervade all aspects of the legal services they provide. Stakeholders argued that lifting the ban on contingency fees could potentially compromise the independence of lawyers and fundamentally change their relationship with their clients, because the lawyer would have a direct financial interest in the outcome.")

134. Email communication with commercial lawyer, Mar. 4, 2019.

135. See Murray, R, "Weeks, Lewis George, (1893-1977)," in Australian Dictionary of Biography, http://bit.ly/2EBui6t (describing a fee arrangement for geological services to an oil and gas company that entitled a geologist to a " $2.5 \%$ royalty on any commercial discovery.")

136. See, e.g., Trustees, Biowatch Trust v Registrar, Genetic Resources and others 2009 (6) SA 232 (CC) (South Africa)

137. This occurred in British Columbia (Ministry of Forests) v Okanagan Indian [2003] SCR 371 (Canada), discussed in Hinson, Z and Hubbard, D, "Access to Justice in Namibia: Proposals for Improving Public Access to Courts, Costs and Contingency Fees," Paper No. 3, Legal Assistance Centre (2012), p. 17.

138. Sargent Shriver National Center on Poverty Law, Federal Practice Manual for Legal Aid Attorneys: 9.4 Attorney Fees, (last updated, 2016), especially paras. 9.4.B.1 and 9.4.C.2, http://www.federalpracticemanual.org/chapter9/section4.

139. See, e.g., Oshlack v Richmond River Council [1998] HCA 11 (Australia) and Singh v Canada (Attorney General) [1999] 4 FC 583 (Canada), discussed in Hinson, Z and Hubbard, D, "Access to Justice in Namibia: Proposals for Improving Public Access to Courts, Costs and Contingency Fees," Paper No. 3, Legal Assistance Centre (2012), pp. 22 and 3.

140. Interview with civil society representative, July 7, 2017. 
141. Allard K. Lowenstein International Human Rights Clinic at Yale Law School, "Governance of Agricultural Concessions in Liberia: Analysis and Discussion of Possible Reforms," (2017), p. 42, https://bit.ly/2XxSpf2 (stating that "communities are unlikely to file claims in court due to a distrust of the legal system" and referring to an interview with a representative of the Liberia Extractive Industry Transparency Initiative who "expressed concerns about the ability of the legal system, still recovering from the war, to settle contract disputes and give meaningful remedies." See also Barendrecht, M, Gramatikov, M, El Khoury, R, Motiejunas, G, Muller, S, Osborne, D, and Heijstek-Ziemann, K, "Justice Needs in Yemen: From Problems to Fairness," HiiL (2014) p. 44, https://bit.ly/2XzsMdU (noting that in Yemen, people were six times more likely to seek information and advice regarding land title disputes from sheikhs, relatives, and other people they knew as opposed to lawyers.)

142. Interview with civil society representative, Jan. 3, 2019 ("Very often, communities aren't aware that they've signed really bad contracts and don't realize that they've signed away all their lands, and it's only when things start to go bad that they realize they have bad contracts. Then the question is, "how do we get out of this?'”). Interview with civil society representative, Dec. 18, 2018 ("When communities were treated badly by concessions, they reached out to CSOs").

143. Although not focusing on communities affected by land or resource investments, more general global and national legal or justice needs surveys have data on citizen legal needs relating land rights issues and land disputes. See World Justice Project, "Global Insights on Access to Justice," (2018), https://bit.ly/2C4OblU and the justice needs surveys of the Hague Institute for Innovation of Law (HiiL) for Bangladesh, Fiji, Jordan, Kenya, Mali, Morocco, Nigeria, Tunisia, the Ukraine, and the United Arab Emirates https://www.hiil.org/projects/?_sf_s=legal\%20needs.

144. LDP, "Developing A Portfolio Of Financially Sustainable Scalable Basic Legal Service Models," Vol. 1,(2015), p. 6. Community members may not have the time or resources to do some tasks themselves, especially where such tasks will interview with their daily livelihood strategies. Where possible, financing initiatives could provide per dia or stipends for community members who participate in formal processes or carry out tasks relating to different investment related processes. One civil society interviewee proposed setting such stipends at the rate of a local labourer; the payment would therefore not be regarded by community members as disproportionately high or attractive, increasing the chances that only the most committed individuals would participate: Interview with civil society representative, Jan. 14, 2019.

145. Organizations such as the International Senior Lawyers Project and Advocates for Development often broker pro bono support from international and national law firms.

146. Orozco, D, "The Use of Legal Crowdsourcing to Achieve Legal, Regulatory, and Policy Objectives,” Vol. 53, Issue 1, 145-192, (2016), p. 149.

147. While not strictly expert sourcing, Rightslink, a student-run human rights law organization based at Columbia Law School offers legal research; requests for research assistance can be submitted at: http://rightslink.law.columbia.edu.

148. Legal Network for Gender Equity and Time's Up Legal Defense Fund, Application for Financial Support for Legal Representation (2018), https://bit.ly/2COE8hM

149. Melas, C, “Time's Up Legal Defense Fund Takes on 1,000 Cases," (Mar. 2018), https://cnn.it/2F66YkE.

150. Relatedly, a financing initiative could be based on an endowment (rather than an endowment fund), where a very large donation to the initiative is managed and invested, and where only the annual investment income is used to finance community support, so that the endowment can survive in perpetuity.

151. World Bank, "Mining Foundations, Trusts and Funds: A Sourcebook," (June 2010), p. 84, https://bit.ly/2TolaL0 (describing the Asociación Los Andes de Cajamarca (ALAC) as annually allocating $\$ 400,000$ of its approximate $\$ 1.5$ million budget to an endowment).

152. World Bank, "Mining Foundations, Trusts and Funds: A Sourcebook," (June 2010), p. 62

153. See, e.g., Maisel, P, "Expanding and Sustaining Clinical Legal Education in Developing Countries: What We Can Learn from South Africa," 30 Fordham Int'l L.J. 374, 378, (2007), pp. 387-388 ("Since 2000, an endowment set up by the Ford Foundation has supported the salary of an additional attorney at most clinics. Unfortunately, after six years, this endowment is running out of funds; thus, the positions it supports are in jeopardy.")

154. See, e.g., discussion of Kumacaya and the RSPO's Dispute Settlement Facility trust fund in "2. Basket funds," above.
155. Interview with civil society representative, Oct. 17, 2018.

156. Interview with civil society representative, Oct. 17, 2018; Interview with civil society representative, July 10, 2017; Interview with civil society representative, Jan. 14, 2019.

157. Interview with foundation representative, Mar. 1, 2019; Interview with civil society representative, Oct. 17, 2018. See also LDP, "Developing A Portfolio Of Financially Sustainable Scalable Basic Legal Service Models," Vol. 1, (2015), p. 78.

158. Interview with civil society representative, Jan. 3, 2019.

159. Interview with civil society representative, Jan. 14, 2019; Interview with multistakeholder body representative, Oct. 4, 2018

160. Interview with DFI representative, Dec. 11, 2018.

161. CCSI, Danish Institute for Human Rights, and Sciences Po Law School Clinic, "A Collaborative Approach to Human Rights Impact Assessments," (2017), p. 56 http://ccsi.columbia.edu/work/projects/chria; Bauer, J, "Stakeholder-Business Engagement Fund: Mapping Fund Components and Strategic Considerations," (Oct. 2014), pp. 14-15; Interview with civil society representative, June 30, 2017.

162. Interview with impact investment fund representative, Nov. 20, 2018

163. Legal Network for Gender Equity and Legal Defense Fund, "Application for Financial Support for Legal Representation," (2018), https://bit.ly/2C0E8hM.

164. Interview with civil society representative, June 30, 2017. See also CCSI, DIHR, and Sciences Po Law School Clinic, "A Collaborative Approach to Human Rights Impact Assessments," (2016), pp. 38-39, https://bit.ly/2SkeZnD (discussing, in the context of collaborative human rights impact assessments (HRIAs), the role of a multistakeholder standing committee that would play an oversight role including approving and authorizing payments to HRIA participants.)

165. Jochnick, C, "Can Corporate Campaigners Tap Corporate Largesse? Unlocking Millions For Human Rights Advocates," Open Democracy, (Dec. 30, 2013), https://bit.ly/2SArVLh ("Attract willing watchdogs. This constitutes the main challenge. Credible watchdogs will tend to be suspicious of anything that benefits (or is paid for by) a corporate adversary. For good reason, watchdogs would assume the Fund is aimed at coopting stakeholders and quelling legitimate protests. Green-washing, dividing and conquering, bribing adversaries are familiar approaches of companies operating in conflict environments. Watchdogs will assume similar shenanigans from the Fund and will be reluctant to risk their reputation and credibility by taking part. However, even the most radical organizations take money from foundations with ties to Wall Street and human rights organizations have willingly joined initiatives funded and driven by company interests (e.g. the various MSIs above).")

166. Email communication with civil society representative, Feb 22, 2019; Interview with foundation representative, March 1, 2019; Interview with civil society representative, March 8, 2019.

167. See, e.g., Toone, R.E., "The Absence Of Agency in Indigent Defense," American Criminal Law Review, p. 59.

168. Interview with impact investment fund representative, July 6, 2017.

169. Interview with civil society representative, Dec. 18, 2018; Interview with civil society representative, Dec. 19, 2018.

170. Interview with multi-stakeholder body representative, Dec. 5, 2018; Interview with civil society representative, Jan. 3, 2019; Interview with civil society representative, July 7, 2017. See also Nielsen, R, "Sustaining the Process of Legal Empowerment," in Justice Initiatives: Legal Empowerment, Open Society Justice Initiative (2013), p. 118, https://osf.to/2EFoZTR (noting that if support that is available is under-utilized, this may mean that there is "a previously unrecognized gap in local capacity, and fund managers can respond by retooling their funding strategy to strengthen the capacity of existing providers or develop new ones.")

171. Interview with civil society representative, Dec. 19, 2018; Interview with civil society representative, Dec. 18, 2018.

172. Interview with civil society representative, Jan. 14, 2019.

173. Interview with civil society representative, Jan. 14, 2019. 
"Donors, support providers, and others have found ways to help communities access legal and technical support in the context of land investments. Yet their combined efforts, and the funding behind them, can only extend so far. Promising new opportunities exist for filling this financing gap. To succeed, these opportunities require catalytic and sustained efforts by a range of different actors. This report presents a call to action to help communities secure the support they so crucially need."

\section{ccsi.columbia.edu}

Columbia Center on Sustainable Investment

Jerome Greene Hall 435 West 116th Street

New York, NY 10027 Phone: +1(212) 854-1830 Fax: $+1(212)$ 854-7946
The Columbia Center on Sustainable

Investment is a leading applied research center and forum dedicated to the study, discussion and practice of sustainable international investment.

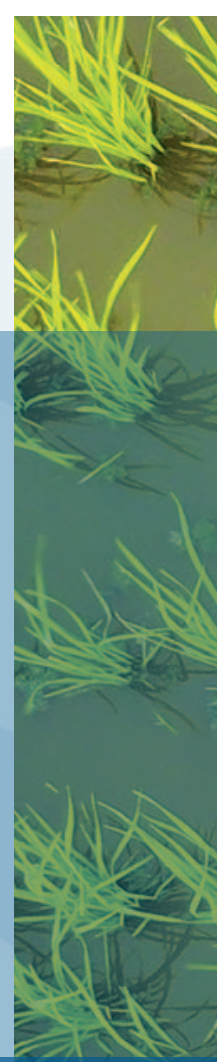

